\title{
I6. Yüzyılın İlk Yarısında Osmanlılar ile Safeviler Arasında Yaşanan Dini ve Siyasi Polemikler
}

\author{
Vural Genç*
}

Kütüphaneleri yıllarca birlikte aşındırdiğ̊ımız

Y. Sezer'in anisina...

\begin{abstract}
Religious and Political Polemics Between the Ottomans and Safavids in the First Half of the $16^{\text {th }}$ Century

Abstract - One aspect of the long-term conflicts between the Ottomans and the Safavids is the strongly religious debates that were perpetuated through various mediums. Unfolding at the end of the Bayezid II's reign (1481-1512) and continuing during the reign of his successors Yavuz Sultan Selim (1512-1520) and Suleiman the Lawgiver (1520-1566), these religious debates followed three different mediums: Ottoman chroniclers' thoughts in their chronicles, anti-Safavid/Qizilbash fatwas adjudicated by ulama circles, and finally diplomatic correspondences between the two sides. Without doubt the last one is the medium in which the religious debates were held most fiercely. In this article, I will focus on the legitimacy debates between the Shah Tahmasb (15241576) and Suleiman the Lawgiver by highlighting the fact that the diplomatic correspondences were a suitable course to present the political thoughts and the religious tenets to the addressee in the form of a manifesto.
\end{abstract}

Keywords: Shah Tahmasb, Suleiman the Lawgiver, Ottomans, Safavids, religious polemics.

\section{Giriş}

Şah İsmail'in Akkoyunlu payitahtı Tebriz'i ele geçirdikten sonra 1501 yılında 12 İmam Şiîliğini resmen ilan etmesi, Şiî İran ile Sünni komşuları Osmanlılar ve Özbekler arasında uzun soluklu bir mücadeleyi de başlattı. Şah İsmail gücünün

* Bitlis Eren Üniversitesi.

Osmanlı ve İran dünyası arasında 15. ve 16. yüzyıllarda yaşanan üstünlük iddiaları ve meşruiyet tartışmaları yazı dizisi çerçevesinde hazırlanan bu çalışma, ilki Osmanlı Araştırmaları’nın 54. sayısında (Haziran 2019) yayınlanan “Timur'u Geçmek: Akkoyunluların Osmanlılara Karşı Üstünlük İddiaları” başlıklı yazının devamı niteliğindedir. 
zirvesinde olduğu 1512'ye gelindiğinde doğuda Kandahar-Belh, batıda BağdatBasra hattı içinde büyük bir imparatorluk vücuda getiren, hatta yoğun bir takipçi kitlesine sahip olduğu Anadolu'da politik egemenlik sahasını Fırat'ın ötesine kadar genişleten genç bir şah, güçlü bir karakter, yenilmez bir savaşçı olarak ün yapmıştı. Şah'ın, Anadolu'da bulunan Kızılbaş topluluklar nezdinde gücünü gitgide hissettirmesi ve nüfuz oluşturması aslında II. Bayezid için adeta büyük bir meydan okumaydı. Bölgedeki dinsel yayılımları ile mevcut statükoyu değiştirebilecek bir yapı arz eden Safeviler, Anadolu'daki takipçileri aracılığı ile Osmanlı topraklarında karışıklık çıkarabilecek güçteydiler. Onların, sınır ötesindeki Kızılbaş takipçilerini yönlendirebilme avantajı, Osmanlı İmparatorluğu için bir tehdit oluşturuyordu. Çünkü Şah İsmail’in iktidarını yasladığı takipçileri, Anadolu'da Babai hareketinden bu yana yerleşik Sünni iktidarlara karşı gelen büyük çoğunluğu göçebe Türk topluluklarıydı. ${ }^{1}$

Bu yeni durum hem Safevîleri hem de Osmanlıları İslam dünyasında hâkimiyet kurabilmek için birbirleriyle çetin bir çatışmaya sevk etmekte gecikmedi. İki taraf arasında iki asrı aşkın sürecek olan bu mücadeleye, savaşlar ve diplomasi kanalıyla sürdürülen üstünlük iddiaları damgasını vurdu. Her bir taraf diğeriyle olan çatışmasını meşru bir zemine oturtup haklı çıkarmak için çeşitli ideolojik araçlara başvurdu. Ancak bu araçların en göze çarpanı hiç kuşkusuz din kisvesine büründürülmüş olanlarıydı. ${ }^{2}$ Hem Safeviler hem de Osmanlılar bu mücadeleyi dinsel bir meşruiyet zemini üzerine temellendirerek gaza, cihad ve nesep gibi benzer politik ve ideolojik aygıtlar kullandılar. Osmanlılar Safevilere karşı kendilerini Sünni dünyanın ve ideolojinin temsilcisi ve İslamın koruyucusu olarak konumlandırırken bu iddialarını ulemadan aldıkları fetvalar ve Kızılbaşlık karşıtı reddiye metinleriyle desteklediler. ${ }^{3}$ Osmanlı uleması Sünni ideolojisini Safeviler ve Anadolu'daki takipçileri için yapılan "Kızılbaş, mülhid, rafızi” gibi tanımlama-

1 Faruk Sümer, Safevi Devleti’nin Kuruluşve Gelişmesinde Anadolu Türklerinin Rolü, (Ankara: Türk Tarih Kurumu, 1976); Jean-Louis Bacqué-Grammont, "XVI. Yüzyılın İlk Yarısında Osmanlılar ve Safeviler," Prof Dr. Bekir Kütükoğlu’na Armă̆an, (İstanbul: İstanbul Üniversitesi Edebiyat Fakültesi, 1991), s. 206.

2 Vecih Kevserânî, Fakih ve Sultan: Osmanlı ve Safevîlerde Din-Devlet İlişkisi, çev. Ramazan Yıldırım, (İstanbul: Yeni Zamanlar Yayınları, 2006), s. 8.

3 Safevi karşıtı propagandistlerinden Şirvânînnin (ö. 1540) bu konudaki risaleleri için bkz. Hüseyin Yılmaz, "İran'dan Sünni Kaçışı ve Osmanlı Devleti’nde Safevî Karşıtı Propagandanın Yaygınlaşması: Hüseyin b. Abdullah el-Şirvânînnin Mesiyanik Çağrısı”, Uluslararası Diyarbakır Sempozyumu (2-5 Kasım 2016), haz. Ufuk Bircan ve diğerleri, (Diyarbakır: T. C. Diyarbakır Valiliği, 2017), s. 299-309. 
lar ve dinsel tartışmalar üzerinden inşa etmeye çalıştı. Safeviler, Osmanlıların bu doktrinel hamlelerine aynı tonda cevap verdiler. Onlar gerçek İslamın temsilcisi olduklarını, Osmanlıların hiçbir dini ve siyasi meşruiyetinin olmadığını ulema çevrelerinden aldıkları görüşler doğrultusunda karşıt metinlerle ilan ettiler. Şah İsmail zamanındaki ilk tartışmalar daha çok politik bir üstünlük çerçevesinde sürdürüldüyse de esas Safevilerle Osmanlılar arasındaki üstünlük tartışmalarının dinsel bir veçhe kazanması, Şiiliğin ciddi bir şekilde kurumsallaşması gibi ideolojik değişimlerin yaşandığı Şah Tahmasb döneminde gerçekleşti. Zira bu dönem, Şah İsmail ile başlayan İran’ın tamamen Şiileştirilmesi adımının, oğlu Şah Tahmasp zamanında başını Cebel Amil kökenli Şii fakih el-Muhakkik el-Kerekînnin (ö. 1534) çektiği ulemanın, müteşerri Şiiliği devlet bürokrasisinde kurumsallaştırmasıyla birlikte büyük bir ivme kazandığı dönemdi. ${ }^{4}$

\section{İlk Dönem Polemiklerine Bir Bakış}

15. yüzyılda Akkoyunluların Osmanlılara karşı yürüttükleri üstünlük mücadelelerini ve diplomasi savaşlarını 16. yüzyıl başında Safeviler değişen ideolojik ve politik söylemleri çerçevesinde devam ettirdiler. Şah İsmail ile II. Bayezid arasındaki üstünlük mücadelesi, yumuşak bir diplomatik tonda sürdürüldü denilebilir. II. Bayezid dönemi Safevilere karşı diplomatik ton ve söylem hususunda haleflerininkinden oldukça farklıdır. ${ }^{5}$ Ancak II. Bayezid döneminin kronik yazarlarının, kendi mecralarında dillendirdikleri konuya dair görüşleri bunun dışında tutulmalıdır. Örneğin Aşıkpaşazâde'den anlaşılacağı üzere Osmanlılar erken dönemlerde bu mezhepsel doktrini Erdebil şeyhlerinden çok Şah İsmail'e atfediyorlard. ${ }^{6}$ Kemalpaşazâde ve daha sonra Celalzâde Mustafa ${ }^{7}$, Safevileri her türlü dini ve siyasi meşruiyetten mahrum bırakacak argümanlara kendi kroniklerinde yer verdiler.

4 Ayrıntılı bilgi için bkz. Said Amir Arjomand, The Shadow of God and the Hidden Imam: Religion, Political Order and Societal Change in Shi ite Iran from the Beginning to 1890, (Chicago-London: The University of Chicago Press, 1984), s. 105-144.

5 II. Bayezid bir taraftan da Safevilerin her türlü faaliyetlerini sıkı bir şekilde takip ediyordu. Padişahın, Erdebil sufîlerinin ele geçirilip idam edilmelerini içeren hükümleri için bkz. İlhan Şahin-Feridun Emecen, Osmanlılarda Divan-Bürokrasi-Ahkâm: II. Bayezid Dönemine Ait 906/1501 Tarihli Ahkâm Defteri, (İstanbul: Türk Dünyası Araştırmaları Vakfı, 1994), s. 78-79, 126.

6 Tevârih-i Âl-i Osman: Aşıkpaşazâde Tarihi, (İstanbul: Matbaa-i Amire, 1332), s. 266-267.

7 Celalzade Mustafa'nın entelektüel biyografisi ve tarih yazımı için bkz. Şahin Kaya, Empire and Power in the Reign of Süleyman: Narrating the Sixteenth-Century Ottoman World (Cambridge: Cambridge University Press, 2013). 
16. yüzyıl Osmanlı tarihçisi Mustafa Âli, Nusretnâme’sinde Şah İsmail'in bu yeni inanca şekil vermek amacıyla bir takım yenilik ve dinsel prensipleri İslamın yetmiş bir farklı fraksiyonundan dilediği gibi seçtiğini yazmıştı. ${ }^{8}$ Buna karşın Safevi kroniklerinde Osmanlı karşıtı böyle bir söyleme rastlanmaz. Her şeye rağmen Safevi saray tarihçileri, Osmanlıların, Şah ve takipçilerine yönelik kullandığı itibarsızlaştırıcı dilin aksine Osmanlı padişahlarından "Rum mülkünün sahibi, Rum memleketinin azametli padişahı" şeklinde saygıyla bahsederler. ${ }^{9}$

Kroniklerde yer alan siyasi ve dini tartışmaların muhataplarına ulaşma güçlügü̈, diplomatik yazışmaları taraflar arasındaki dinsel ve siyasal polemiklerin en canlı olarak sürdürüldüğü mecra yapmıştır. Şah İsmail ile II. Bayezid arasında gerçekleşen diplomatik yazışmalar çerçevesinde II. Bayezid'in mektupları tembihler ve yer yer gözdağıyla dolu olsa da bu tür tartışmalara rastlanmaz. II. Bayezid 1504'te Şah İsmail'e Akkoyunlu Sultan Murad'ı mağlup etmesini tebrik mahiyetinde bir elçilik heyeti gönderdi. Gerçek amacı neler olduğunu öğrenmek olan padişah mektubunda Şah'ın Akkoyunluları yenmesinden duyduğu memnuniyeti dile getiriyor, mezhebini yaymak için şiddet kullanmaktan kaçınmasını, reayaya karşı adil olmasının gerekliliğini, yoksa Cengiz ve Timur gibi zalim sıfatıyla anılacağını vurguluyordu. Mektupta sıklıkla görülen tembihler yanında Şah İsmail'e "seyyid soylu, velâyet hanedanlı, Dârâ ve Keyhüsrev’in veliahdı, Şeyh Sultan Haydar'ın oğlu, İran'ın kadim hanedanına mensup soylu ve necib zat” şeklinde hitap ederek aslında onun soya dayalı meşruiyetini onaylıyordu. ${ }^{10} 1507$ Dulkadır seferi münasebetiyle II. Bayezid'e gönderdiği mektuba cevaben padişahın, kendisine "melik-i memâlik-i Acem, Noyan-ı bilâd-1 Türk ve Deylem, Cemşîd-i devrân, Keyhüsrev-i zaman, el-müeyyed min indillah" gibi dini ve dünyevi sıfat ve unvanlarla hitap etmesi Şah İsmail'in meşruiyetini tanıdığı anlamına geliyordu. ${ }^{11}$ II. Bayezid'in kullandığı bu İslamî ve İranî unvanları bizzat zâtı için formüle eden Şah İsmail'in kendisiydi. Divan'ında soyunun bir taraftan 7. İmam üzerinden Hz. Ali'ye dayand1ğını belirtirken (anamdur Fatima, atamdur Ali), diğer taraftan Ferîdûn ve Cemşîd

8 J. R. Walsh, "The Historiography of Ottoman-Safavid Relations in the Sixteenth and Seventeenth Centuries," Historians of the Middle East, ed. Bernard Lewis \& Peter Malcolm Holt, (London: Oxford University Press, 1962), s. 207.

9 Şah İsmail ile Yavuz Sultan Selim arasındaki mektuplaşmalar için bkz, İranlı Tarihçilerin Kaleminden Çaldıran (1514), haz. Vural Genç (Feridun Emecen'in giriş yazısıyla), (İstanbul: Bengi Yayınları, 2011), s. 93-115, 152-155.

10 Mektup için bkz. İranlı Tarihçilerin Kaleminden Çaldıran (1514), s. 67-71.

11 Iranlı Tarihçilerin Kaleminden Çaldıran (1514), s. 75. 
gibi karizmatik İran şahlarına dayandırarak Farisî ve İslamî (Perso-İslamik) bir hükümdar imajını ortaya koymuş ve bu mirası devraldığını iddia etmişti. Özbek hanı Şeybek Han'ın Şah İsmail tarafından 1510 yılında yenilerek öldürülmesi ve kesik başının II. Bayezid'e gönderilmesi, Padişah’ı öfkelendirdiğinden olsa gerek, Şah’a yazdığı mektubunda II. Bayezid eski tembihlerine ilaveten "Rum ülkesini istila etme” düşüncesinden vazgeçme çağrısında bulunuyordu. ${ }^{12}$ II. Bayezid, Şah' 1 hem İran'ın meşru varisi hem de hükümdarlığı Tanrı tarafından teyit edilen bir kimse olarak takdim etmektedir. Şah ise Bayezid ile olan diplomatik yazışmalarında ona "hazret-i hilâfet-destgâh, sultan-1 selâtîn-i İslam, el-gâzî fi sebilullah, elmüeyyed min indillah, hazret-i hüdâvendigâr-1 İslam, hâris-i havza-i mülk ve din” gibi İslamî unvanlarla hitap ederek gaza ve hilafet gibi iki önemli İslamî referansı Bayezid için kullanmıştı. ${ }^{13}$ II. Bayezid ile Şah İsmail arasındaki diplomatik yazışmalar aynı zamanda iki ülke arasındaki mutedil ve temkinli ilişkiyi de resmeder niteliktedir. Bu dönemde her iki tarafın diplomatik yazışmalarında bir üstünlük tartışması olmadığı gibi II. Bayezid'in, Şah İsmail'in soya dayalı meşruiyetini tartışmadığı görülür. Bu iddianın bir diğer kanıtı da İdris-i Bidlîsînnin 1506 yılında tamamladığı Heşt Behişt in ilk nüshasında Safeviler ile Osmanlılar arasında bu yönlü bir meşruiyet tartışmasının yer almayışıydı. Oysa saray ve ulema çevresinde ciddi anlamda böyle bir tartışma olmuş olsaydı Bidlîsî bunu ustalıkla dinsel referanslar kullanarak formüle edebilirdi. Nitekim Bidlîsî̀nin Osmanlılarla Çukurova bölgesindeki mücadeleleri çerçevesinde Memlük meşruiyetini sorguladığı ve kabul etmediği bilinmektedir. ${ }^{14}$ Bununla beraber Şah İsmail'in soya dayalı iddialarının asılsız olduğu, soylu bir hanedana mensup olmadığı gibi nesebinin babasına nispetinin dahi şüpheli olduğu şeklindeki iddialar daha sonraki Kızılbaşlık karşıtı reddiye külliyatıyla ortaya çıkmıştır. ${ }^{15}$

1501'den bu yana elde ettiği büyük kazanımlar sonucu kısa zamanda İran'da hâkimiyet sağlayan Şah İsmail'in Sultan II. Bayezid'in topraklarından geçerek 1507 yılında Dulkadırlı Alaüddevle’yi (ö. 1515) mağlup etmesi, ardından 1510 yılında Özbek hanı Şeybanî Han’a karşı aldığı galibiyet ve onun başını keserek gözdağı olsun diye II. Bayezid'e göndermesi Safeviler için bir siyasal üstünlük

12 Iranl Tarihçilerin Kaleminden Çaldıran (1514), s. 76-77.

13 Feridun Ahmed Bey, Münşeâtǚs-Selâtîn, I, (İstanbul: Matbaa-i Amire, 1274), s. 345-347.

14 İdris-i Bidlîsî, Heşt Behişt, Nuruosmaniye, nr. 3209, vr. 541a; Vural Genç, "Acem’den Rum'a”: İdris-i Bidlîsînnin Hayatı, Tarihçiliği ve Heşt Behişt’ in II. Bayezid Kısmı (1481-1512)” (yayınlanmamış doktora tezi), İstanbul Üniversitesi Sosyal Bilimler Enstitüsü, 2014, s. 642.

15 Risâle fi Tekfir-i Kizılbaş, Milli Kütüphane, no. Yz. A695, vr. 5a-6a. 
iddiası sayılırdı. Erdebil Dergâhı'na bağlı Anadolu’daki Kızılbaş takipçilerinin sayıca çokluğu ise bu üstünlüğün bir başka nişanesiydi. Bidlîsî, Şah İsmail'in bu avantajlı konumunu adeta Şah’a söylettiği “İran’ı baştanbaşa kılıçla aldım, Tatar şahının başını Kayser'e (II. Bayezid) hediye ettim, Rum’dan Şam’dan müritlerim, Hindistan'ın ötelerinde Rum'dan ordum vardır" sözleriyle teyit eder. ${ }^{16}$ Safevilerin bu avantajlı konumu ile beraber elde ettikleri kazanımlar, Osmanlı karşısındaki üstünlük iddialarının zeminini oluşturmuş gözükmektedir. Hatta o derece ki, Şah İsmail'in Rum'u alma fikri de işte bu dönemlerde belirmiş olmalıdır. Nitekim yukarıda bahsedildiği gibi II. Bayezid'in bir mektubunda Şah'ı Rum'u istila fikrinden vazgeçirme çağrısı, Şah İsmail'in “alub Şam u Rûm'ı müsahhar kılub, pes andan hevâ-yı Fireng eylerem" ${ }^{17}$ satırları ile beraber okunduğunda böyle bir düşüncenin var olduğunu gösterebilir. Bütün bunlara rağmen iki taraf arasındaki üstünlük tartışmalarının II. Bayezid döneminde çok fazla yaşanmadığı söylenebilir. Hemen belirtilmelidir ki II. Bayezid dönemi kronik yazarlarının kendi mecralarında Safevilerin meşruiyetini tartışmaları ve II. Bayezid ile Şah İsmail arasındaki diplomatik yazışmalar ton ve içerik açısından hiçbir zaman Selim ve Kanunî dönemlerindeki gibi diplomatik teamülleri aşan bir tarzda olmadı. ${ }^{18}$

Safevilerin dinsel meşruiyetlerine yönelik ilk hamleler Selim’in iktidarının ilk yıllarında fetva, reddiye metinleri ve mektuplaşmalar üzerinden yapıldı. Padişah 1514 baharında İran üzerine bir sefer düzenlemeye karar verdiğinde bu sefere meşru bir gerekçe oluşturmak maksadıyla ulemadan fetvalar aldı. Safevileri şeriat sınırlarının dışına konumlandıran bu fetvalar, aynı zamanda Şii doktrine karşı bir hamleydi. ${ }^{19}$ Sefer boyunca ardı ardına gönderdiği mektuplarında, Şah İsmail’i savaşa davet eden, dini ve dünyevi meşruiyet iddialarını kabul etmeyen, hakaretamiz tona sahip ifadeler kulland $1 .{ }^{20}$ Mektuplarında şahı, dinin temellerini yıkmakla,

16 Mektubun tam metni için bkz. Vural Genç, "Şah ile Sultan Arasında Bir Acem Bürokratı: İdris-i Bidlîsîn nin Şah İsmail'in Himayesine Girme Çabası,” Osmanlı Araştırmaları, 46 (2015), s. 43-75.

17 Şah İsmail Hatai Külliyatı, haz. Babek Cavanşir-Ekber N. Necef, (İstanbul: Kaknüs Yayınlar1, 2006), s. 503.

18 Bunun bir farkına varış olup olmadığı noktasındaki bazı fikirler için bk. Feridun M. Emecen, “Şark Meselesinin Doğuşu: Osmanlı Devleti'nin Şark Meselesinin Ortaya Çıkışı”, Osmanl Klasik Çağında Siyaset, (İstanbul: Kapı Yayınları), 2018, s. 342-363.

19 Osmanlı ulemasının Safevi karşıı fetvalarındaki farklı yaklaşımları için bkz. Abdurrahman Atçll, "The Safavid Threat and Juristic Authority in the Ottoman Empire During the 16th Century”, International Journal of Middle East Studies, 49 (2017), s. 295-314.

20 Savaşın seyri hakkında geniş bilgi için bkz. Feridun M. Emecen, Yavuz Sultan Selim, (İstanbul: Yitik Hazine Yayınları, 2010), s. 87-145; Iranlı Tarihçilerin Kaleminden Çaldıran (1514), s. $92-132$. 
mescitleri yıkıp Kuran’ hiçe saymakla, günahsız Müslümanları öldürmekle itham ediyordu. Padişah ordu harekete geçtikten sonra bile mektuplar göndermeye devam etti. Şah İsmail'e gönderdiği ikinci mektubunda kendisini İskender ve Feridun, şahı ise Dehhak ile özdeşleştiren padişahın, diğer mektuplarına hâkim olan havanın yanında ilk mektubunda da kısmen bahsettiği dikkat çekici bir çağrı daha vardı: Muhammedî sünnete tabi olduğu ve ülkesini Osmanlı topraklarından bildiği vakit kendisini affedeceğini belirtiyor, aksi takdirde tacını başından alıp memleketinde taş üstünde taş bırakmamakla tehdit ediyordu. ${ }^{21}$ Selim, Şah'a gönderdiği mektuplarında onu kan dökücü, alçak ve günahkâr sufioğlu, şeytan ordusunun lideri, lanetli inatçıların önderi, din ve dünya haramîlerinin başı ve zamanın Dehhak'ı olarak nitelerken Şah cevâbî mektubunda Selim'e İslamın sığınağı, din ve devlet savaşçısı, İslam ve Müslümanların koruyucusu, büyük sultan şeklinde hitap etmeyi tercih etmiştir. ${ }^{22}$

Sultan Selim'in üstünlük beyanı taşıyan bu mektupları, gücünün zirvesindeki Safevi tarafında da bu iddialara karşı argümanlar üretilmesine ve tartışılmasına yol açtı. Çaldıran Savaşı arifesinde adeta diplomatik bir savaş gerçekleşiyordu. Safevi tarafı bu iddialara üst perdeden cevap vermekte gecikmedi. Şah İsmail'in bu yönlü içeriğe sahip ilk mektubu kısa sürede Sultan Selim'e ulaştı. Yavuz Sultan Selim’in mektupları Safevilere karşı bir takım üstünlük iddiaları taşıdığından Şah’ın mektubun tonu da bu yönde oldu. Şah İsmail'in bu mektubu, aynı zamanda padişahın mektuplarına karşılık verilmiş tek cevap niteliği taşıyordu. Selim' in seferin başlangıcından bu yana gönderdiği her üç mektubuna hâkim olan tehdit, aşağılama ve savaş çağrısına daha yumuşak ve itidal çağrısı yapan diplomatik bir dille cevap verdi. Şah İsmail, Selim'in bu seferine ve husumetine neyin sebep olduğunu anlayamadığını, gazi soylu o hanedanla ilişkilerinin çok eskiye gittiğini, babası Bayezid zamanında iki ülke arasındaki ilişkilerin dostane olduğunu vurguluyordu. Anadolu'nun ekser ahalisinin kendi müritleri olduğunu vurgulaması, Osmanlıların Timur dönemindeki gibi bir kargaşayı tekrar yaşamamaları temennisi ise gözdağıyla karışık bir hatırlatmaydı. Şah İsmail, Isfahan'dan gönderdiği bu mektubunda iki tarafın da birbirini incitmesine gerek olmadığını, husumetlerin eskide kaldığını, dostluktan dolayı bu cevabı yazma gereği duyduğunu belirtir. ${ }^{23}$ Mektuba hâkim olan bu soğukkanlı ve umursamaz tavırla padişaha Timur'un Yıldırım Bayezid'e hücumunu

21 Iranlı Tarihçilerin Kaleminden Çaldıran (1514), s. 104.

22 Şah İsmail ile Yavuz Sultan Selim arasındaki mektuplaşmalar için bkz, İranlı Tarihçilerin Kaleminden Çaldiran (1514), s. 93-115, 152-155.

23 Iranl Tarihçilerin Kaleminden Çaldıran (1514), s. 110-111. 
hatırlatarak savaşta ısrar ettiği takdirde akıbetinin iyi olmayacağını, atası Yıldırım Bayezid'in kaderine ortak olacağını belirtmesi apaçık bir gözdağıydı.

Şah İsmail’in itidal çağrılarına sahip, iki taraf arasında düşmanlığın olmadığını vurgulayan ama aynı zamanda Timur-Yıldırım hadisesini hatırlatan gözdağı içerikli mektubu, dedesi Uzun Hasan dönemindeki tartışmaları hatırlatır. ${ }^{24}$ Timurlularla aralarında bağ kurmaya çalışan Safevilerin, Osmanlılarla siyasi çekişmelerinde Timur imajını tıpkı Akkoyunlular gibi ön plana çıkarmaktan geri durmamaları bu minvalde bir devamlılık şeklinde yorumlanabilir. Safevilerin Osmanlılara karşı yürüttükleri üstünlük tartışmalarının Selim'in saltanatının ilk yıllarına rastlaması bir tesadüf değildi. Dikkat edilecek olursa Timur darbesi üzerinden verilen mesaj ve hatırlatmaların Safeviler tarafından güçlü bir şekilde dillendirilmesi Şah İsmail'in iktidarının mutlak olarak güçlendiği, yenilmez bir hükümdar olarak hafızalara kazındığı bir dönemin tartışmaları olarak görülebilir.

Bu acı Timur yenilgisi hatırlatmasını bu kez yapan, dedesi Uzun Hasan gibi gaza misyonuyla ortaya çıkan ve Anadolu’da her anlamda çok güçlü bir nüfuza sahip olan Şah İsmail'in kendisiydi. Gerçekten de hem Şah İsmail'in Divan'ına hem de erken dönem Safevi kroniklerine bakıldığında Safevilerin bu gaza misyonunu üstlendikleri, hatta Müslüman dünyanın koruyuculuğu rolüne dahi soyundukları görülebilir. Örneğin Şah İsmail, Şeybek Han'a yazdığı bir mektupta Meşhed'i alıp hac yolunu kontrol edeceğinden bahsederken Şeybek Han, bunun karşılığında hilafet ve imametin Tanrı tarafından kendilerine verildiğini iddia etmişti. Dolayısıyla her iki taraf da Meşhed ve Mekke hac yolları üzerinden dini/siyasi bir polemiğe girmiş ve İslam dünyasının temsilcisi olma iddialarını dile getirmişlerdi. ${ }^{25}$

Şah İsmail, padişaha Timur hatırlatması yaparken tıpkı dedesi Uzun Hasan gibi en çok da Anadolu'daki sosyo-politik nüfuzuna güveniyordu. Uzun Hasan'ın Anadolu'yu Timur'dan çok daha iyi bildiği iddiaları ${ }^{26}$, Şah İsmail'in Anadolu'daki hareket sahası ve ağlarını gösteren arşiv belgeleri sayesinde daha ete kemiğe bürünmüş haldedir. Şah, gerçekten de geniş halifeler ağı sayesinde Anadolu'da olup biten her şeyden haberdar oluyordu. Üstelik bu halifeler, büyük kitleleri mobilize

24 Vural Genç, “Timur'u Geçmek: Akkoyunluların Osmanlılara Karşı Üstünlük İddiaları,” Osmanlı Araştırmaları, 54 (2019), s. 27-57.

25 Şah İsmail ile Özbek hanı Şeybek Han arasındaki yazışmalar için bkz. Shah Ismail-e Safavî: Esnad va Mukatebat-e Tarikhi-ye Iran az Timur ta Shah Ismail Hamrah ba Yaddashtha-ye Tafsili, haz. Abd al-Hossein Navai, (Tehran: Muassasa-ye Motalaat-e Islami, 1370/1991), s. 81-88.

26 Ayrıntılı bilgi için bkz. Genç, "Timur'u Geçmek”. 
ederek İran'a gönderiyorlardı. Şah İsmail'in iktidarının ilk zamanlarına ait bir belge bu mobilizasyonun nasıl yürütüldügüünü, Şah’ın Anadolu’da nasıl bir nüfuz elde ettiğini gösterebilir. Belgeye göre Şah’ın adamlarından Muhammed Ağa Bukavul ve İbrahim Halife, Anadolu'da birçok Türkmen beyini harekete geçirmiş, bu Türkmen beyleri de asker toplayarak Şah’a biat ettikleri haberini göndermişlerdi. Şah İsmail onların toplu değil de küçük gruplar halinde gelmelerini tavsiye etmişti. ${ }^{27}$ Şah’ın, Turgud kabilesinden Musa Turgudoğlu'na göndermiş olduğu bir başka mektup, Safevîlerin Anadolu'daki yerli haberci ve casuslarının varlığı ve bu casus ağının nasıl işlediği hakkında önemli bilgiler vermektedir. ${ }^{28}$ Yine Mayıs 1510 tarihli bir diğer mektubunda Şah İsmail'in, bütün Karaman'ın sözünden çıkmadığı nüfuzlu bir şahsı himaye ettiğini belirtmesi Anadolu’yu çok iyi tanıma iddiasında ne kadar haklı olduğunu gösterir. ${ }^{29}$ Anadolu'yu çok iyi tanıma ve tebaası arasında söz sahibi olma şeklindeki üstünlük iddiası tıpkı Uzun Hasan’ın Fatih'e karşı mektubunda ileri sürdüğü üstünlük iddiasına benzemektedir. ${ }^{30}$

Osmanlılar ile Safeviler arasındaki bu üstünlük polemiği, Çaldıran Savaşı arifesinde diplomatik yazışmalar üzerinden yaşandı. Safevilerin özellikle Osmanlılarla karşı karşıya gelmekten kaçınması, Osmanlı casuslarının Şah İsmail’in savaş niyetinde olmadığı şeklinde getirdiği haberler, esas savaş meydanlarında nihai hesaplaşmaya dönüşmesi beklenen üstünlük mücadelesinin diplomatik yazışmalara yansımasına neden olmuş gözükmektedir. ${ }^{31}$

Çaldıran Savaşı ile beraber yenilmez şah imajının zarar görmesi ilk bakışta Safevilerin bu tür iddialarından vazgeçtiklerini düşündürebilir. Oysa durum hiç de böyle olmadı. Bu üstünlük iddialarına rağmen yenilen taraf olan Safeviler, bir müddet sonra tekrar aynı iddiaları gündeme taşıdılar. Hem bu seferki tartışmalar Safevilerin Osmanlılarla karşı karşıya gelmekten kaçınmasından kaynaklı olsa gerek çok daha sert oldu. Her iki hükümdar arasında polemik konusu olan üstünlük tartışmaları haleflerine devredildi. Haleflere devredilen bu üstünlük tartışmaları, Kanunî Sultan Süleyman ve Şah Tahmasb dönemindeki Irakeyn seferleri sırasında yaşandı. Osmanlıların ateşlemesiyle Safevilerin sürdürdüğü tartışmaların en belirgin yönü Şii doktrin esaslı oluşuydu. Her iki taraf arasındaki diplomatik yazışmalar, bu üstünlük tartışmalarının yansıdığı yegâne mecraydı.

27 TSMA. E. 881/21.

28 John E. Woods, "Turco-Iranica I: An Ottoman Intelligence Report on Late Fifteenth/

Ninth Century Iranian Foreign Relations," Journal of Near Eastern Studies, 38 (1979), s. 4.

29 TSMA. E. 698/56.

30 Genç, "Timur'u Geçmek”.

31 Iranlı Tarihçilerin Kaleminden Çaldıran (1514), s. 106. 


\section{Şah Tahmasb'ın Osmanlı Karşıtı Üstünlük İddiaları}

Kanunî Sultan Süleyman, İslamın koruyucusu, halife ve sahib-kıran sıfatıyla ilki 1533, ikincisi 1548 ve sonuncusu 1553 olmak üzere İran üzerine üç sefer düzenledi. Bu üç sefer esnasında da Safevi ordusu ateşli silahlar üstünlüğüne sahip Osmanlı ordusu ile karşı karşıya gelmekten kaçındı. Kanunî̉ nin bu sefer için meşru gerekçesi tıpkı babası Selim’in olduğu gibi İslamın koruyucusu olma idi. Celalzade Mustafa, 1533 'teki ilk seferi "Kızılbaşların İslam dininin birçok hükmünü değiştirmiş olmaları" şeklindeki dinsel bir gerekçeye bağlıyordu. ${ }^{32}$ Osmanlı ordusu bu seferler esnasında Tebriz, Hemedan ve Bağdad üçgeninde faaliyet yürüttüyse de sadece Bağdad'da uzun bir müddet kalıcı olabildiler. Her iki taraf arasında bir meydan savaşının yaşanmaması, dolayısıyla kazanan ve kaybedenin belli olmaması üstün tarafın belirlenmesini zorlaştırdı. Savaş meydanlarında elde edilemeyen bu üstünlük haliyle diplomatik yazışmalara yansıdı. Daha açı bir ifade ile taraflar savaş meydanında karşılaşamayınca üstünlüğün ifade edileceği yegâne mecra diplomatik yazışmalar oldu. Osmanlılar ve Safeviler bu üstünlük mücadelesini gaza-cihad, sahip olunan toprakların genişliği ve nüfuz sahası, İslamın hamiliğini üstlenme, Timur gibi bir sabib-kırandan daha üstün olma ve soydan gelen üstünlük gibi çeşitli meşruiyet araçları üzerine kurgulamışlardı.

1533 ve 1548 'deki seferler boyunca iki taraf arasında gerçekleşen yazışmalarda diplomatik teamülleri aşan bir üstünlük mücadelesi yaşanmadı. 1533 seferi münasebetiyle yazdığı mektubunda Kanunî, Şah Tahmasb’ savaşa davet ediyor, itaat etmesi gerektiğini söyleyerek yakın zamanda Tebriz, Azerbaycan, Horasan ve bütün İran'da hâkimiyet kuracağını vurguluyordu. ${ }^{33}$ En sert siyasi-dinsel polemikler ve üstünlük mücadeleleri, 1553 yılında Nahçivan'a yapılan son sefer esnasındaki diplomatik yazışmalara yansıdı. Bunda Safevi tarafının bir meydan savaşından kaçınmasının etkisi olduğu söylenmelidir. Bu seferki ton ve ifadeler alışılagelenden çok farklı ve diplomatik teamülleri aşan sertlikteydi. Kanunî, savaşa davet için Tahmasb’a gönderdiği mektubunda onu dini değiştirmekle, ilk üç halifeye ve $\mathrm{Hz}$. Aişe'ye küfürle (teberrailik) ve dinden dönmekle itham ediyor, açıkça Müslüman olmaya davet ediyordu. Ayrıca geçen seferlerin aksine Safevi reayasını esir edeceğini söyleyerek İran'ı bir darüll-harb olarak ilan ediyordu. Kanunî mektubunda "kâfirlere karşı sürekli gaza ve cihad ettiğini", gerçek maksadının ise "İslamı ihya

32 Celalzade Mustafa, Geschichte Sultan Süleymân Kânûnîs von 1520 bis 1557, oder Tabakât ül-Memâlik ve Derecât ül-Mesâlik von Celâlzâde Mustafâ genannt Koca Nişâncı, ed. Petra Kappert, (Wiesbaden: Steiner, 1981), s. 250a.

33 Münşeatü̉s-Selâtîn, I, s. 541-43. 
etmek" olduğunu vurguluyordu. ${ }^{34}$ Celalzâde’nin kaleme aldığı bu mektup, gerçek bir Osmanlı üstünlüğünden ziyade barış yapmaya hazır olan sultanın retoriklerini yansitiyordu. ${ }^{35}$

Kanunî̀nin mektubunda yer alan bazı aşağılayıcı ifadeler, Tahmasb cephesinde çok daha sert bir karşılık buldu. Şimdiye kadarki yazışmalarda saygıda kusur etmediklerini belirten Tahmasb, bu sert karşılığa gerekçe olarak son gelen mektupların -ki Ahmed Paşa'nın ve diğer serhad paşalarının mektupları buna dâhildir- aşağılayıcı ifadelerini gösterir. Tahmasb bu uzun mektubunda gelen mektubun içeriğinden de özetle bahsederek üslubunun neden sertleştiğini anlamamıza yardımcı olur. Tahmasb’ın belirttiğine göre gelen mektupta 12 İmam inancından el çekmedikçe doğru yolu bulamayacakları, ilk üç halifeye saygı göstermedikçe sulhun mümkün olamayacağı vurgulanmıştı. Ayrıca Safevi ümerasının Osmanlı serhad paşalarına yazdığı mektuplar, "Kızılbaş ordusunun düştüğü acziyetten dolayı barış istemesi ve diz çökmesi” şeklinde takdim edilmişti. Tahmasb’ı oldukça sinirlendiren bu mektup, aynı zamanda bu dinsel ve siyasal polemiklerin ateşleyicisinin ilk olarak Osmanlı tarafı olduğunu açığa kavuşturur.

1554 yılında Tahmasb’’n Kanunîye gönderdiği manifesto niteliğindeki bu uzun mektupta yer alan üstünlük tartışmaları ve Sünnilik karşıtı söylem siyasal ve dinsel olmak üzere iki ana polemik ekseninde şekillenmişti. İlk tahta çıktığında "Turan mülkü sultanları, Maveraünnehr, Hıtay ve Hoten hanlarının İran'ı sahipsiz sanıp” 250 bin askerle Horasan'a yaptıkları saldırıları püskürterek onları yenilgiye uğrattıkları, Şirvan'ı ve hiç kimsenin alamadığı Herat'ı bileğinin gücüyle alarak 12 İmam adına hutbe okuttukları, Maveraünnehr hanlarını itaat altına aldıkları şeklindeki ifadeler Osmanlılara karşı formel bir gözdağı mahiyeti taşıyordu. Tahmasb'ın bu fetih vurgusu Kanunî̀nin Yemen ve San'a’yı fethettiği yönündeki ifadesine ve imparatorluk için çizdiği geniş sınırlara kendi cephesinden bir cevap niteliğindeydi. Şah’ın kendilerine ait olan Van ve Bağdad yanında Yemen ve San'a'yı da Osmanlıların hileyle ele geçirdiklerini söylemesi mektuptaki başlıca siyasal polemik konularındandı. Tahmasb bu siyasal polemikler çerçevesinde padişahın İran'a hâkim olma düşüncesine cevap olarak "İstanbul'a çadırını kurup, Mervânî Osmanlı sancağını alaşağı edeceğini, Van'dan İstanbul'a kadar her yeri 40 gün içinde yok edebilecek güçte” olduklarını söyler. Osmanlı ordusunun “Tebriz’de halkın sert direnişi ile karşılaşması ve 300 bin kişiyle, top ve tüfekle

34 Münşeatüs-Selâtîn, II, s. 19-25.

35 Zahit Atçll, "Warfare as a Tool of Diplomacy: Background of the First Ottoman-Safavid Treaty in 1555", Turkish Historical Review, 10 (2019), s. 15-16. 
gelen padişahın bir gün bile Tebriz'de kalmadan geri dönmesi” Tahmasb’a göre üstünlük ve zafer nişanesidir. Yukarıda da denildiği gibi bu satırlar Kanunînnin “Tebriz, Azerbaycan, Horasan ve bütün İran'da hâkimiyet kuracağı” ifadelerinde cevaben kaleme alınmıştı. Ancak daha sonra bu uzun ve yıpratıcı savaşların bir sonuç getirmediğini gören padişahın, Tahmasb’a yazdığı bir başka mektubunda “Aden, Sind, San'a ve Habeş'ten güneşin battığı yere kalan olan bütün yerlerin kendi tasarruflarında olduğunu karga ve baykuş yatağı olup harabeden ibaret olan Acem mülküne ihtiyaç duymadığını” belirtmesi bu fikrinden vazgeçtiğini gösterir. ${ }^{36}$ Padişahın bu iddialarla ortaya çıkması ve karşı tarafa duyurması Tahmasb' da bu konuda tetiklemiş gözükmektedir. Mektubunda Tahmasb'ın, İstanbul'a çadırını kurup Osmanlı hanedanını yok edeceğini ve Rum Sultanı'nın tahtına oturacağını söylemesi bir tehditten öte babası Şah İsmail zamanından beri hem şah hem de takipçileri arasında dolaşımdaki bir düşünceyi temsil etmektedir. İdris-i Bidlîsînnin Şah İsmail'i İstanbul'u almaya davet etmesi ${ }^{37}$ yanında Şah Tahmasb'ın muasırı $^{38}$ ve Safevi şahlarına olan bağlılık şiirleriyle bilinen Kızılbaş şair Pir Sultan Abdal'ın "İstanbul şehrinde ol sahib devlet, tac-ı devlet ile salınmalıdır”, "Şah Urum'a gele bir gün”, "Şah İstanbul'da otura” satırları okunduğunda bu fikrin şahın takipçileri arasında da dolaşımda olduğunu gösterir. ${ }^{39}$ Bunun da ötesinde hem Şah Tahmasb'ın rüyası hem de İran entelektüel dünyasında tartışılan Safevilerin yakın zamanda Osmanlılar ve Özbekleri yenecekleri düşüncesi böyle bir misyonun biçildiğini gösterir. ${ }^{40}$

Her iki taraf arasındaki üstünlük mücadelesinin bir başka veçhesi de dinsel polemiklerdir. Mektupta üzerine dinsel polemiğin sürdürüldüğü ilk meşruiyet aracı gaza ve cihad oldu. Kanunî̀nin "kâfirlere karşı gaza” ettikleri vurgusu ve bu sıfatla İslamın koruyucusu olma iddiası Tahmasb'da da karşılık buldu. Tahmasb her yıl Gürcistan tarafında gaza ile meşgul olduklarını söyleyerek bir bakıma kendilerinin de İslamın koruyucuları sıfatıyla üstün oldukları vurguluyordu. Kardeşi Elkas Mirza bile Kanunîye sığınma talebini içeren mektubunda "kâfir Çerkeslere

36 Abd al-Hossein Navai, Shah Tahmasb-e Safavi: Asnad va Mokatabat-e Tarikhi Hamrah ba Yaddashtha-ye Tafsili, (Tehran: Entesharat-e Bonyad-e Farhang-e Iran, 1350), s. 275.

37 Genç, "Şah ile Sultan Arasında Bir Acem Bürokratı".

38 Pir Sultan Abdal, haz. Abdülbaki Gölpınarlı-Pertev Naili Boratav, (İstanbul: Kapı Yayınları, 2017), s. 37-38.

39 Pir Sultan Abdal, s. 28, 32.

40 Şerif Ali Tûsî, Mübeşsere-ye Şâhiyye, Tehran Meclis Kütüphanesi, no. 21519. 
karşı gaza ettiğinden” bahsetmesi Safevilerin bir İslamî meşruiyet aygıtı olarak gazayı ne denli önemsediklerini gösterir. ${ }^{41}$

Tahmasb, soylarına yönelik ileri sürülen yalancı seyyidlik iddiasını reddederek seyyid soylu olduğunu vurguluyor ve buna karşın Osmanlı padişahlarını Hz. Hüseyin'i katledenleri rehber alanlar şeklinde takdim ediyordu. Mektubuna "Mervân'ın sünnetini ihya eden itikatsız ve imansız Osmanlılar" diye başlayan Tahmasb, "İstanbul'daki puthanenin keşişi, din tüccarı, cahil” olarak hitap ettiği Kanunînin "üç halifeye küfretmeyi terk etmeden barışın mümkün olmadığını" belirttiği bir başka mektubuna göndermede bulunur. Hilafet tartışmaları burada da kendisine yer bulmuştur. Tahmasb, hilafet hakkının Hz. Muhammed tarafından vasi olarak ilan edilen Hz. Ali'ye ait olduğunu söyler ve Kanunî̀yi bu konuda hiçbir şey bilmemekle, etrafındaki ulemayı da konuya dair tek bir kitap dahi okumamakla itham eder. Hilafet tartışmalarında Tahmasb, Sünni kaynaklara da referans vererek bir taraftan onlara hakim olduğunu belirtmek isterken, diğer taraftan da Kanunîyi ve Osmanlı ulemasını bu kaynakları bilmemekle itham etmiştir. Sünni ulemanın Kızılbaşlara karşı verdikleri fetvalara da değinen Tahmasb, onların cahil ve sapkın olduklarını, iddiaların aksine bütün şer' i yükümlülükleri yerine getirdiklerine yer verir. Bu vesile ile "mahremi bilmeyen, köpek ve domuzdan içtinap etmeyen” ifadeleriyle aşağıladığı Osmanlı ulemasının Acem’in en cahilleriyle bile ilmi bahislere girişemeyeceğini iddia eder. Şiilik ve Sünnilik ayrımına da değinen Tahmasb, Şia’nın Hz. Muhammed zamanından beri var olduğunu oysa Sünniliğin ise Muaviye ile ortaya çıktığını ve Muaviye'nin sünnetini sürdürmek demek olduğunu iddia ediyor, Osmanlıların Rafızî tanımlamasına karşısında kendilerinin de Osmanlıları Haricî, Yezidî ve Mervanî olarak tanımladıklarını söylüyordu. Hindistan'dan Arap ve Acem'den Mağrib'e kadar kendi Ehl-i Beyt sancaklarının dalgalandığını söyleyen Tahmasb, bir nevi hâkimiyet sahasını çizer. Rum, Maveraünnehr ve Hindistan'da bile çok sayıda takipçisi olduğunu ve günden güne arttığını söyleyen Tahmasb bu vesile ile Osmanlılara olan üstünlüğünü belirtir.

Mektubun kuşkusuz en ilginç ve çarpıcı yanı Tahmasb’ ’n başlattığı soy tartışmasıdır. Tahmasb, Kanunî̀yi “soysuz ve cahil bir ecdada” sahip olmakla itham eder. Daha da ileri giderek padişahın soyunun Rumî ve Frengî gulamlarla karıştığını, ecdadının ise yüce soylu muteber hanedanlar arasında yer almadığını söyler. Bu soy tartışmasının hanedanın meşruiyeti açısından çok önemsendiği söylemek gerekir. Akkoyunluların da Osmanlılara karşı böyle bir soy tartışmasına girdikleri

41 Navai, Shah Tahmasb-e Safavi, s. 171. 
burada hatırlanmalıdır. ${ }^{42}$ Tahmasb’’n bu soy tartışması İslamın ve Müslüman dünyanın koruyuculuğunu üstlenme noktasında Osmanlılara karşı bir üstünlük mesajı içerdiği açıktır. Kendisine gelen mektubun içeriği çok aşağılayıcı olsa gerek Şah, bundan böyle Osmanlıları "Ümeyye, Mervan, Bermekî ve Abbasî lanetlilerinden” sayacağını, Osmanlıları lanetlemeleri için İran, Horasan ve Azerbaycan'da teberraîyânı sokaklara salacağını, hatta Ermeni ve Yahudilerin hayvanlarının nalları altına Kanunînin adını yazdıracaklarını söylüyordu.

Ardından Timur'un soyundan gelen Babürlü Hümâyûn Şah'tan bu üstünlük tartışması vesilesiyle bahis açar. Tahmasb, sahib-kıran ve adil hüsrev olarak takdim ettiği Hümâyûn'un sahip oldukları topraklar, kudret ve hazine zenginliği açısından Kanunî̀den daha üstün ve seçkin olduğunu belirtir. Ordusunun sadece süvarilerinin beş yüz bin civarında olduğunu ve savaş zamanlarında on iki bin fil çıkarabildiğini abartılı bir dille vurgular. Mektubun sonundaki ifadeler daha çarpıcıdır. Gördüğü rüyayı, yakın bir zamanda Rum sultanlarının kendisine itaat edeceğinin müjdelenmesi şeklinde yorumlayan Tahmasb belki de Kanunî̀yi kızdıracak satırları en sona sakladı. Yakın gelecekte Osmanlı topraklarını düşmanlarından temizleyeceğini vurgulayan Tahmasb, Kanunînin de tıpkı Yıldırım Bayezid'in cihangir padişah sahib-kıran Emir Timur Gurkan'ın elinde tutsak olduğu gibi gazilerin elinde tutsak olacağını ve teberrâîlerin baltasılla öldürüleceğini söylüyordu. Acem dünyasının Rumî dünya karşısındaki üstünlüğü Timur'la Yıldırım arasındaki savaşla sembolize edildiği için Safeviler Osmanlıların yaşadığı bu travmayı her fırsatta hatırlattıkları diplomatik bir silaha dönüştürdüler.

Tahmasb'in bu mektubunda yapılan birçok siyasi ve dini polemik, dönemin kroniklerinde oldukça bilindik ve tartışılan şeylerdi. Ancak bunların dışında daha önce hiç aşina olmadı̆̆ımız husus, soy tartışması oldu. Osmanlı padişahlarının soylarına gönderme yapıp, onları soysuz olmakla suçlarken Tahmasb bunun karşılığında kendi soyunun üstünlügüne ve İslamî meşruiyetlerine vurgu yapıyordu. Topkapı Sarayı evrakı arasında Şah Tahmasb’a ait Farsça bir nesebnamenin yer alması, bu soy tartışmalarının iki taraf arasındaki bir müddet devam ettiğini, Tahmasb'ın seyyid soylu olduğunu göstermek için karşı tarafa böyle bir nesebname gönderdiğini düşündürür niteliktedir. ${ }^{43}$ Bu üstünlük tartışmasında Tahmasb kendisini Hz. Ali ve Ehl-i Beyt üzerinden Hz. Muhammed’in, Kanunî̀yi ise "hilafet tahtını gasp eden ilk üç halifenin” takipçisi olarak konumlandırıyor, meşruiyeti-

42 Bkz. Genç, “Timuru Geçmek”.

43 TSMA. E. 752/1. 
ni bu yolla devşirirken Osmanlı padişahlarının hiçbir meşruiyetinin olmadığını vurguluyordu. Tahmasb hem bir taraftan üstünlük tartışmasını Osmanlılarla kendileri arasında sürdürürken diğer taraftan Osmanlılarla Timur ve onun ardılları Babürlü hükümdarları ile Maveraünnehr hanları arasında devam ettirdi. Ona göre hem Timur bir "sahib-kıran ve cihangir padişah" olarak hem de Babürlü Hümâyûn Şah ve Maveraünnehr hanları Osmanlı padişahlarından çok üstündü. Bu üstünlük hem soyca hem de güç, zenginlik ve ihtişamla gelen bir üstünlüktü. Tahmasb, aslında her ne kadar Timur'a denk olduklarını söylese de bir bakıma Timur'dan daha üstün oldukları mesajını satır aralarında veriyordu. Şöyle ki, Yıldırım Bayezid'in yaşadığı trajediyi de hatırlatarak kendisinin Timur gibi Rum ülkesini yeniden fethedeceğini belirtmesi ve Timurlu ardılları sahib-kıran Babürlü Hümâyûn Şah’ın "kendi eşiklerine biat ettiğini” vurgulaması kendisi için çizdiği emperyal imajın bir parçasıydı. Bir bakıma kendisini Timur soylu sahib-kıranın dahi biat ettiği kimse olarak takdim etmişti. ${ }^{44}$ Mektubun son satırlarına saklanan "küfr ve inadından vazgeç ki masum imamlardan (eimme-i ma’sumîn) şefaat bulasın” şeklindeki açık çağrı Kanunî̀nin Safevileri İslama davet çağrısının aynı tonda cevabı niteliğindeydi. Aslında dönemin Osmanlı kronikleri de Kanunî̀yi Timur ile özdeşleşen sahib-kıran unvanı ile tavsif ederken Celalzâde, Timur'u Kanunîye kul olma (Timur-gulam) mertebesine getirmiştir. ${ }^{45}$

Mektup, taşıdığı mesaj açısından Uzun Hasan'ın meçhul bürokratının kaleme aldığı mektuba benzer niteliktedir. ${ }^{46}$ Tahmasb’’n ileri sürdüğü bütün üstünlük iddialarının taşıdığı mesaj, İslam dünyasının gerçek temsilcisinin Safeviler olduğu şeklindedir. Bunun için Safevilerin gazi misyonunu, peygamber soylu oluşlarını ön plana çıkararak Osmanlı tarafını bu meşruiyet aygıtlarından mahrum etmeyi hedefler. Dikkat edilecek olursa Tahmasb' in mektubu da tıpkı Akkoyunlu Uzun Hasan'ın direktifleri ile yazılıp gönderilen mektubunda olduğu gibi Osmanlıların meşruiyetini temelden sorgular niteliktedir. Tahmasb'ın Safeviler için çizdiği bu üstün imaj aslında yapmayı umduğu antlaşmada elini güçlendirmeye yönelik bir hamleydi. ${ }^{47}$ Mektuptaki tartışmalar, Osmanlıların siyasal ve dinsel anlamda hiçbir

44 Abu'l-Qasem Haydar İvoghli, Majma al-Insha, Ketabkhane-ye Majlis-e Shura-ye Melli, no. 606; Navai, Shah Tahmasb-e Safavi, s. 203-237. Mektuba dair değerlendirmeler için bkz. Colin Paul Mitchell, The Practice of Politics in Safavid Iran: Power, Religion and Rhetoric, (London-New York: I.B. Tauris Publishers, 2009), s. 81-88.

45 Celalzade Mustafa, Geschichte Sultan Süleymân Kânûnîs von 1520 bis 1557, s. 291a. 46 Genç, "Timur'u Geçmek”.

47 Atçıl, "Warfare as a Tool of Diplomacy”, s. 17. 
meşruiyetinin olmadığı iddiası için özenle seçilmiştir. Diğer bir deyişle siyasal ve dinsel polemiklerle dolu olan bu mektup, Şii ulemanın kurumsallaştırdığı Safevi devlet ideolojisinin, dönüşüm yaşayan Ortodoks Şii doktrinin Osmanlı tarafına beyanı için iyi bir mecra olmuş gözükmektedir.

Tahmasb’n sert bir tonla giriştiği bu dinsel polemiklerin, Şii müctehid, mürevvic-i mezheb Şeyh Ali Kerekînin (ö. 1534) kurumsallaştırdığı imamî doktrinin birer parçası ve yansıması olduğunu tahmin etmek güç değildir. Şah İsmail'in erken saltanat yıllarında himayesine giren Şii müctehid el-Kerekî, Sünnilik karşıtı sert söylemleri ve risaleleriyle İmamî doktrini bütün İran'da birleştirmeyi başardı. ${ }^{48}$ Ortodoks Şiiliğin ilanı olan bu dönüşüm çerçevesinde 1531 ve 1534 yıllarında yayımlanan fermanlarla şarabın ve müzik aletlerinin yasaklanması gibi bir takım şer'i uygulamalar hayata geçirildi. ${ }^{49} \mathrm{Bu}$ dönüşümün en büyük izleri 1532 yılında Şah Tahmasb' ın Özbek hanı Ubeydullah Han'a yazdığı mektupta görülebilir. ${ }^{50}$ Tahmasb’ın Özbek hanına yazdığı bu mektup ton ve içerik açısından 1554 yılında Kanunîye yazacağı mektubun hemen hemen aynısıydı. Bu iki Sünni hükümdara gönderdiği iki mektup da geniş hacimli olup mektupların en çarpıcı yönü imamî doktrindeki tartışmalara ve Sünni karşıtlığına yer vermesiydi. ${ }^{51}$

Tahmasb'in polemiklerle dolu bu mektubu, Osmanlı tarafında büyük bir yankı uyandırdı. Kanunî bu mektuba cevap verme gereği duymadı. 1555'e doğru iki tarafın da barış temayülü yavaş yavaş ortaya çıktığı için mektupların tonu da haliyle biraz daha yumuşadı. Tondaki bu yumuşamaya rağmen daha önceki mektuplarda ortaya konulan polemiklere özellikle de soy ve üstünlük gibi zaman zaman ortaya çıkan tartışmalara bir cevap vermek gerekiyordu. İşte Osmanlı cenahındaki esas tartışma Tahmasb'ın Timur üzerinden kendisi için çizdiği üstünlük imajı oldu. Padişahın yerine İskender Paşa cevabi bir mektup kaleme alarak Tahmasb'ın vezirlerine gönderdi. Mektubunda İskender Paşa, padişah hakkında söylenilen bu çirkin ve kaba şeyler karşısında şaşırıp kaldığını, aynı şeyleri kendilerinin şah için dillendiremeyeceklerini söylüyordu. Paşa, mektubun içeriğinin

48 El-Kerekî̀ nin Şiiliği kurumsallaştırıcı rolü için bkz. Arjomand, The Shadow of God and the Hidden Imam, s. 132-137; Mitchell, The Practice of Politics in Safavid Iran, s. 71-88.

49 Hasan-1 Rumlu, Ahsanu't-Tawarikh, I, ed. C. N. Seddon, (Baroda: 1931), s. 246.

50 Mektup için bkz. Navai, Shah Tahmasb-e Safavi, s. 35-44. Mektup Özbek hanı Ubeyd Han'ın 936/1529-30 yılında gönderdiği mektuba cevaben kaleme alınmıştı. Özbek hanı mektubunda Şah'ı Safevi idaresindeki Herat'ta camileri meyhane ve ahıra çevirmekle, şeyheyne küfretmekle suçluyordu. Hasan-1 Rumlu, Ahsanu't-Tawarikh, s. 226-233.

51 Mitchell, The Practice of Politics in Safavid Iran, s. 73. 
başından bilinmesi durumunda divanda okumaya bile gerek görmeyeceklerini belirtiyordu. Sözü Şah Tahmasb’ sinirlendiren ve böyle bir mektup kaleme almasına neden olan mektuba getiren paşa maksatlarının şahın etrafındakileri eleştirmek olduğunu, doğrudan şahı hedef almadıklarını belirtiyordu. Bu da Kanunînin mektupları yanında Tahmasb’ı kızdıran ve böyle bir cevap yazmaya zorlayan başka mektupların da varlığından bizi haberdar eder ki Tahmasb'ın "edepsiz şeyler" olarak belirttiği Ahmed Paşa’nın mektubuydu. İskender Paşa'nın üstelik "sahibkıranın bendeleri” olarak daima cihat üzere olduklarını belirtmesi Tahmasb'ın gaza-cihad misyonu vurgusuna bir gönderme niteliği taşıyordu. ${ }^{52}$

Kanunî, Tahmasb’’n bu sert mektubuna cevap verme gereği duymayınca ikili arasındaki bu diplomatik yazışmalar bir alt düzeye düşürüldü. Üstünlük tartışmaları, dinsel ve siyasal polemikler şimdi her iki tarafın vezirleri ve vükelası arasında devam ettiriliyordu. Veziriazam Ahmed Paşa’nın Şah Tahmasb'a ve Erzurum beylerbeyi Ayas Paşa’nın Şah’ın vükelasına gönderdiği, içerik yönünden Kanunî̀nin mektuplarını andıran mektuplarında Safevileri her zamanki gibi küfürle itham ediyorlar, dini polemiklerin iki tarafın da uleması arasında tartışılmasını teklif ediyorlardı. Her iki isim de Şah'ın bu olay yaratan mektubunu hedef almışlar, mektuptaki iddia ve ithamlara zehir zemberek cevaplar vermişlerdi. Veziriazam Ahmed Paşa, Kızılbaşların iman sahibi olduklarının tartışmalı olduğunu söylerken, Safevilerin henüz 50 yıl önce kurdukları yeni mezhepleriyle hiçbir şekilde Müslüman olmadıklarını iddia ediyor ve bunun kanıtlanması için her iki tarafın ulemasını tartışmaya davet ediyordu. ${ }^{53}$ Ayas Paşa ise kendisi, mirzaları, hanları ve her yana gönderdiği halifeleriyle Şah Tahmasb’ın memleketinin sınırlarını olduğundan fazla genişletme sevdasına düştüğünü belirtiyordu. Ayas Paşa’nın burada kastettiği şey, Tahmasb'ın mektubunda Hind ve Maveraünnehr'den başlattığı hâkimiyetini İstanbul'a kadar ulaştırma niyeti şeklindeki ifadeleri idi. Paşa bunların ham hayal olduğunu söylüyordu. ${ }^{54}$

İki taraf arasındaki bu mektuplaşmalar 1553-1555 yılları arasında gerçekleşti. Safevilerin Osmanlı karşısındaki üstünlüğü tartışması bir kez daha ortaya çıkmıştı. Her ne kadar bu tartışmayı ilk başlatan, Kanunînnin sapkın ve dinsiz olarak gördüğü, İslamın hamisi olarak ortadan kaldırmak istediği Safevi şahı Tahmasb gibi görünüyorsa da durum öyle değildi. Tahmasb’n Kanunî ve diğer ümeranın

52 Navai, Shah Tahmasb-e Safavi, s. 301.

53 Peçevî Tarihi, I, (İstanbul: Matbaa-i Amire, 1283), s. 318-321.

54 Peçevî Tarihi, I, s. 322-325. 
mektuplarına cevaben kaleme aldığ 1 bu uzun mektubu, sert ve aşağılayıcı bir tona sahip olmasının yanında tarihsel olarak Şiilik ile Sünnilik arasındaki siyasal ve dinsel polemikleri ve Şii kimliği hafızasını konu edinen tam bir manifesto niteliği taşıyordu. Mektup bir yönüyle de Osmanlıların "teolojik ve doktrinel saldırılarına” Safevilerin verdiği bir cevapt1. ${ }^{55}$

\section{Sonuç}

16. yüzyılın ilk yarısı boyunca Osmanlılar ve Safeviler arasında devam eden diplomatik yazışmalar, hem Sünni hem de Şii ideolojinin karşı tarafa ilanı için bir araç olarak kullanıldı. Her iki taraf da bu mecrayı kullanarak kendi üstünlüklerini ilan etmek ve karşı tarafın ideolojisi ve doktrinine saldırmak için kıyasıya rekabete girdi. İslamın gerçek temsilcisinin kendileri olduğunu öne süren her bir taraf, bir diğerini siyasî ve dinî meşruiyet iddialarından mahrum bırakmak için çeşitli politik ve ideolojik araçlara başvurdu. Kronikler, reddiyeler, fetvalar ve diplomatik yazışmalar, özellikle taraflar arasındaki teolojik tartışmaların ana mecrası oldu. Osmanlılar bu mecraların hepsini birden kullanırken Safeviler güçlerinin zirvesinde oldukları, Şii fikhının kurumsallaştığı ve bunun Safevi ideolojisini inşa ettiği dönemde sadece diplomatik yazışmalar üzerinden Osmanlılara karşı bir dizi üstünlük tartışmasına girdiler. Bu aslında Şii fikhına dayanılarak formüle edilen Safevi ideolojisinin karşı tarafa propagandasından başka bir şey değildi.

Üstünlük tartışmalarının ton ve içeriği, Safevi ideolojisinin ciddi bir tehdit olarak algılanmaya başlanmasından sonra değişim gösterdi. Şah İsmail'in II. Bayezid ve I. Selim'e gönderdiği mektuplarda üstünlük ve meşruiyetini vurgulamak için dinsel argümanları çok fazla ön plana çıkarmadığı söylenebilir. Çaldıran Savaşı’ndan sonra 16. yüzyıl boyunca devam eden ilişkileri çerçevesinde Safeviler Osmanlılarla bir daha karşı karşıya gelmekten kaçındılar. Şah Tahmasb zamanında savaş meydanlarında bir nihai hesaplaşma gerçekleşmeyince ve kazanan taraf belli olmayınca bu üstünlük mücadelesi haliyle diplomatik yazışmalara yansıdı. Özellikle Safevi tarafı bu üstünlük iddialarını, Osmanlıları savaştan vazgeçirip barışa zorlamak için siyaseten bir baskı aracı olarak da kullandı. Şah İsmail, Çaldıran öncesinde, Şah Tahmasb ise Irakeyn Seferleri esnasında bu iddiaları dillendirdiler. Osmanlı karşıtı bu üstünlük tartışmasının Şah Tahmasb döneminde çoğunlukla dinsel bir veçhe taşıdığı ve kapsamlı olduğu söylenmelidir. Bu da tartışmayı başlatan taraf olan Osmanlı ulemasının, Şii doktrinine yönelik saldırılarına cevap niteliği taşır.

55 Mitchell, The Practice of Politics in Safavid Iran, s. 81. 
Acem dünyasında Osmanlılara karşı kurgulanan bu üstünlük tartışmalarının içinde Timur'a ayrıca yer verilmesinin neredeyse bir gelenek halini aldığı görülür. Akkoyunlular, Safeviler en sonunda da Babürlüler Timur'un yol açtığı yıkımın getirdiği travmayı çeşitli vesilelerle Osmanlılara hatırlattılar. Bu aynı zamanda Acem dünyasını temsil eden güçlerin Timurlularla aralarında bir bağ kurdukları anlamına geldiği gibi Timur gibi güçlü bir imaj üzerinden rakiplere mesaj vermek olarak yorumlanabilir. Hem Şah İsmail'in hem de Şah Tahmasb’ın mektubunda da yer alan Timur-Yıldırım hatırlatması, Herat şeyhülislamının, Ali Şîr Nevâî adına kaleme aldığı mufassal risalenin referans verilmesi gibi bazı ifadeler Timurî meşruiyet ve mirasın Safevi dünyası için hala bir üstünlük ölçütü olduğunu gösterir.

16. Yüzyılın İlk Yarısında Osmanlılar ile Safeviler Arasında Yaşanan Dini ve Siyasi Polemikler

Öz — Osmanlılar ile Safeviler arasındaki uzun süreli mücadelelerin bir ayağını da çeşitli mecralarda sürdürülen dinsel tartışmalar oluşturur. II. Bayezid'in iktidarının son yıllarında başlayıp Yavuz Sultan Selim ve Kanunî Sultan Süleyman dönemlerinde devam eden bu tartışmalar, Osmanlı kronik yazarlarının kendi mecralarında konuya dair belirttikleri görüşleri, ulemanın verdiği Safevi/Kızılbaş karşıtı fetvalar ve iki taraf arasındaki diplomatik yazışmalar üzerinden sürdürüldü. Kuşkusuz bu sonuncusu, tartışmaların en hararetle sürdürüldügü mecra oldu. Bu makalede mevcut dini ve siyasi polemiklerin bir manifesto şeklinde karşı tarafa duyurulduğu ve karşılıklı çekişmeye dönüştürüldüğü diplomatik yazışmalar ekseninde Şah Tahmasb ile Kanunî Sultan Süleyman arasındaki hararetli meşruiyet tartışmalarına değinilecektir.

Anahtar kelimeler: Şah Tahmasb, Kanunî Sultan Süleyman, Osmanlılar, Safeviler, mezhebî polemikler.

\section{Kaynaklar}

\section{Arşiv Belgeleri}

Topkapı Sarayı Müzesi Arşivi (TSMA. E.) 698/56.

TSMA. E. 752/1.

TSMA. E. 881/21.

\section{Yazmalar}

Abu'l-Qasem Haydar İvoghli: Majma al-Insha, Ketabkhane-ye Majlis-e Shura-ye Melli, no. 606.

İdris-i Bidlîsî: Heşt Behişt, Nuruosmaniye Kütüphanesi, no. 3209.

Risâle fi Tekfir-i Kızılbaş, Milli Kütüphane, no. Yz. A695.

Şerif Ali Tûsî: Mübeş̧̧̧ere-ye Şâhiyye, Tehran Meclis Kütüphanesi, no. 21519. 


\section{Diğer Kaynaklar}

Arjomand, Said Amir: The Shadow of God and the Hidden Imam: Religion, Political Order and Societal Change in Shi ite Iran from the Beginning to 1980, Chicago-London: The University of Chicago Press 1984.

Atçl, Abdurrahman: "The Safavid Threat and Juristic Authority in the Ottoman Empire During the 16th Century", International Journal of Middle East Studies, 49 (2017), s. 295-314.

Atçll, Zahit: "Warfare as a Tool of Diplomacy: Background of the First Ottoman-Safavid Treaty in 1555", Turkish Historical Review, 10 (2019), s. 3-24.

Bacqué-Grammont, Jean-Louis: “XVI. Yüzyılın İlk Yarısında Osmanlılar ve Safeviler," Prof. Dr. Bekir Kütükoğlu’na Armăgan, İstanbul: İstanbul Üniversitesi Edebiyat Fakültesi 1991, s. 205-220.

Celalzade Mustafa: Geschichte Sultan Süleymân Kânûnîs von 1520 bis 1557, oder Tabakât ül-Memâlik ve Derecât ül-Mesâlik von Celâlzâde Mustafâ genannt Koca Nişâncı, haz. Petra Kappert, Wiesbaden: Steiner 1981.

Emecen, Feridun M.: Yavuz Sultan Selim, İstanbul: Yitik Hazine Yayınları 2010. .: Osmanlı Klasik Çă̆ında Siyaset, İstanbul: Kapı Yayınları 2018.

Feridun Ahmed Bey: Münşeâtü’s-Selâtîn, I-II, İstanbul: Matbaa-i Amire 1274.

Genç, Vural: “Acem'den Rum'a”: İdris-i Bidlîsînin Hayatı, Tarihçiliği ve Heşt Behişṫin II. Bayezid Kısmı (1481-1512)”(Yayınlanmamış Doktora Tezi), İstanbul Üniversitesi Sosyal Bilimler Enstitüsü, 2014.

.: "Şah ile Sultan Arasında Bir Acem Bürokratı: İdris-i Bidlîsînnin Şah İsmail'in Himayesine Girme Çabası," Osmanlı Araştırmaları, 46 (2015), s. 43-75.

.: “Timur'u Geçmek: Akkoyunluların Osmanlılara Karşı Üstünlük İddiaları,” Osmanlı Araștırmalar, 54 (2019), s. 27-57.

Hasan-1 Rumlu: Ahsanu't-Tawarikh, I, ed. C. N. Seddon, Baroda: 1931.

Iranlı Tarihçilerin Kaleminden Çaldıran (1514), haz. Vural Genç (Feridun Emecen’in giriş yazısıyla), İstanbul: Bengi Yayınları 2011.

Kevserânî, Vecih: Fakih ve Sultan: Osmanlı ve Safevîlerde Din-Devlet İlişkisi, çev. Ramazan Yıldırım, İstanbul: Yeni Zamanlar Yayınları 2006.

Mitchell, Colin P.: The Practice of Politics in Safavid Iran: Power, Religion and Rhetoric, London-New York: I.B. Tauris Publishers 2009.

Navai, Abd al-Hossein: Shah Tahmasb-e Safavi: Asnad va Mokatabat-e Tarikhi Hamrah ba Yaddashtha-ye Tafsili, Tehran: Entesharat-e Bonyad-e Farhang-e Iran 1350.

.: Shah Ismail-e Safavî: Esnad va Mukatebat-e Tarikhi-ye Iran az Timur ta Shah Ismail Hamrah ba Yaddashtha-ye Tafsili, Tehran: Muassasa-ye Mutalaat-e Islami 1370. 
Peçevî Taribi, I, Matbaa-i Amire, İstanbul 1283.

Pir Sultan Abdal, haz. Abdülbaki Gölpınarlı-Pertev Naili Boratav, İstanbul: Kapı Yayınları 2017.

Sümer, Faruk: Safevi Devletinin Kuruluşve Gelişmesinde Anadolu Türklerinin Rolü, Ankara: Türk Tarih Kurumu 1976.

Şah İsmail Hatai Külliyatı, haz. Babek Cavanşir-Ekber N. Necef, İstanbul: Kaknüs Yayınlar1 2006.

Şahin, İlhan-Emecen, Feridun: Osmanlılarda Divan-Bürokrasi-Ahkâm: II. Bayezid Dönemine Ait 906/1501 Tarihli Ahkâm Defteri, İstanbul: Türk Dünyası Araştırmaları Vakfi 1994.

Şahin, Kaya: Empire and Power in the Reign of Süleyman: Narrating the Sixteenth-Century Ottoman World, Cambridge: Cambridge University Press 2013.

Tevârih-i Âl-i Osman: Aşıkpaşazâde Tarihi, İstanbul: Matbaa-i Amire 1332.

Walsh, J. R.: "The Historiography of Ottoman-Safavid Relations in the Sixteenth and Seventeenth Centuries," Historians of the Middle East, ed. Bernard Lewis-Peter Malcolm Holt, London: Oxford University Press 1962, s. 197-211.

Woods, John E.: Turco-Iranica I: An Ottoman Intelligence Report on Late Fifteenth/ Ninth Century Iranian Foreign Relations," Journal of Near Eastern Studies, 38 (1979), s. 1-9.

Yılmaz, Hüseyin: “İran’dan Sünni Kaçışı ve Osmanlı Devleti’nde Safevî Karşıtı Propagandanın Yaygınlaşması: Hüseyin b. Abdullah el-Şirvânî̀nin Mesiyanik Çağrısı,” Uluslararası Diyarbakır Sempozyumu (2-5 Kasım 2016), haz. Ufuk Bircan ve diğerleri, Diyarbakır: T.C. Diyarbakır Valiliği 2017, s. 299-309. 


\section{EK}

\section{ŞAH TAHMASB'IN KANUNİ SULTAN SÜLEYMAN'A MEKTUBU}

(Abu'l-Qasem Haydar İvoghli, Majma' al-Insha, Ketabkhane-ye Majlis-e Shura-ye Melli, nr. 606; Navai, s. 203-237)

Bismillahirrahmanirrahim. Her türlü kusur ve yanlışliktan münezzeh olan, zeval bulma ve eksiklikten uzak olan lütuf, ihsan ve azamet sahibi Allah'a sükürler olsun. Kitabı, peygamberleri ve masum imamları yoluyla açık delille bize kendisini idrak ettiren el-Kerî'dir. Rahmetiyle bizi kötü heva ve hevesten, batul mezheplerden, zalim ve asilere tabi olmaktan kurtaran er-Rahîm'dir. Haşim sülalesinden ve 'Adnan soyundan doğruluk yolunun şefaat eden masum imamın merhametiyle bize bă̆rşlayan, ceddimiz Muhammed'in -ki Kur'an'ı ona indirmiş ve kendisinden birer delil olan masum imamları onun yolunda birbiri ardına getirerek sair dinleri batıl kılmıștır-şeriatına revaç vermeyi bizlere nasip eden er-Rauf'dur. Salat ve selam elçisi ve sevgilisi, yeryüzüne gönderilen Muhammed'in ve onun Ehl-i Beyti'nin, hanedanının, yakîn sahibi imamlarının ve din emînlerinin üzerine olsun ki onlardan ilki Kur'an nassiyla pak olan Emîrül-Müminîn Ali b. Ebi Tâlib'tir. Sonuncusu ise beklenen imam Muhammed el-Mehdi-yi sâhib-zaman'dır. Allah'in salatı kıyamet gününe kadar onların, evladının, ashabının, dostlarının, seçilmişlerin, mücahitlerin ve takipçilerinin hepsinin üzerine olsun. Allah'in rahmeti onlara, laneti ise düsmanlarına ve muhaliflerine olsun.

Bu kutlu mektubun girişi, mülkü istediğine verir ${ }^{56}$ hükmünü kendi kudret divanının münşisinin keramet kalemiyle, hikmet divanının katibinin mis kokulu kalemiyle bizim şahlık sayfamıza yazan mülk sahibinin adıyla süslüdür. Sonsuz hamd ve senalar yaratıcının dergahının beğenilmiş zatına olsun ki adalet, saltanat, padişahlık, azamet, hilafet ve cihangirlik sancaklarımızı Allah, sizden inanıp iyi işlerde bulunanlara, onlardan önce gelip geçenleri nasıl yeryüzüne sâhip ve hâkim kıldıysa onları da mutlaka yeryüzüne sâhip ve hâkim kılmayı ve onlara, râzı ve hoşnût oldukları dîni nasîp edip o dini, bütün dinlerden üstün etmeyi, korkularnı emniyete tebdil eylemeyi vaad etmiştir ${ }^{7}$ doğru vaadi gereğince şüpheye mahal bırakmayacak şekilde göklerin zirvesine yükseltti ve Hazret-i Seyyid-i Kâinât'ın zürriyetinden gelen en iyi yaratılmışlar zümresinden yüce soylu seyyidleri, dindar mevâlîleri, Ehl-i Beyt'in, Haydar-i Kerrâr’’n ve Şiîlerin muhiplerini ve sadık imamları zeval bulmayan kutlu

56 Kur'an: $3 / 25$.

57 Kur'an: 24/55. 
devletimiz vasıtasıyla soysuz münafıkların, kara bahtlı hakir Hâricî Sünnilerin korkusundan uzak ve güvenli kıldı. Din düşmanlarının, tayyibîn-i tahirîn zümresinin muhaliflerinin çoğu perişan, onların kibir ve zorbalık sancakları alaşağı oldu. Bizim saltanat ve şehriyârlık kösümüzün âvâzesini, sonsuz kudret sahibinin desteğiyle, Ahmed-i Mürsel'in şeriatının yardımıyla, Haydar-ı Saf-der'in ve On İki İmamlar'ın Allah'in selamı onların üzerine olsun muhabbetiyle Allab'in yardımı ve fetih geldiği zaman ${ }^{58}$ sedası ve Şüphesiz biz sana apaçık bir fetih verdik ${ }^{59}$ lafzının gönüller açan nidasıyla mavi göklerin sağlam hisarının tepesinde kıyamet suru üfleninceye kadar yankılandırdı. Günden güne artan bu devlet, Elborz Dağı kadar sağlam ve payidardır, yüce temelleri ise ahir zamana kadar ayakta kalacaktır. Dünya ve dünyalılar bizim kutlu sancağımızın altında, bizim emn ü eman gölgemizde refah içindedirler ve öyle de kalacaklar.

\section{Bu felekler döndükçe dem bizim demimizdir \\ Zaman arzu ettiği sürece ad bizim adımızdır}

Bu sözlerin ispatı, bu üslubun tasdik edicisi şudur: İmansız, kötü itikatlı Âl-i Ziyâd, Âl-i Mervân ve Âl-i Osman'ın geleneklerini ihya eden zat [Kanunî Sultan Süleyman], bu arada bir kez daha bazı şeytanların vesvesesiyle ve kapıldığı rüzgarıyla mağrurlanmış, yeryüzünün en iyi mülkü, cennetten bir nişane olan İran mülkünün padişahı olma hevesi ve şahlık hayali onun zihninde yer tutmuştur. Eşkıya gibi olan askerlerinin çokluğuna güvenerek Allah'ın bu devlete olan sonsuz kereminden gafil bir şekilde Azerbaycan memleketine hareket etmiş. Devletimiz onun kötülükleriyle baş edebilecek güçte olmasına rağmen, uğursuz Rum taifesinin şekavet adımlarını Nahçivan vilayetine attığı, buralarda zulüm ve yıkım hususunda fısk u fücur sancaklarını yükselttikleri şeklinde bize haber ulaştırdılar. Reayayı korumak şöhretli hakanlar ve adil sultanlar için önemli bir sorumluluktur. Askerlerimizden bir kısmını zafer alametli ordumuzdan ayırarak o sınıra gönderdik. O imansız Frenklerin, Âl-i Mervân'ın kılıç artıklarının Nahçivan'da yağma yaptıkları mahallere casuslarımızdan birini göndererek onları muzaffer ordumuzun gelişinden haberdar ettik. Onlar da köpekler gibi kaçarak Arslandan kaçan yabani eşek gibidirler ${ }^{60}$ canlarını ülkelerine attılar. Dünyayı satın alan ama dini satan o kimsenin kulaklarındaki gaflet pamuğunu çıkardılar. O bedbaht kıtlık, zorluk, açlık ve çeşitli illetlerin getirdiği sıkıntıyla perişan bir şekilde talihsizlik yükünü

58 Kur'an: 110/1.

59 Kur'an: 48/1.

60 Kur'an: 74/50-51. 
eşeğe yükleyip Diyarbekir'e kadar hiçbir yerde durmaksızın göçtü. Devletimizin azameti karşısında takat getiremeyerek Ancak hiçbir çıkış yoluna gücü yetmeyen ve gö̧ etmeye yol bulamayan ${ }^{61}$ olarak hezimete yüz çevirmiş, onun her bir askeri bir tarafa kaçarak çer çöp gibi darmadağın olmuştu. Böylece fetih ve galibiyet rüzgarı Allah yardım ederse sizi kimse yenemez ${ }^{62}$ bağından esmeye başladı. İslambol keşişlerinin talihsizlik tozu ve mihnet buharı göklere çıktı. Bu olaylar esnasında bahtiyar evlat, pehlivanlık ormanının aslanı, Allah'ın inayetine mazhar olan, hem esirin hem de özgürün dilleriyle övdüğü İsmail Mirza Bahadur Allah onun ahvalini iyi etsin çokça çaba göstererek felek ihtişamlı, şöhretli bazı ümera ve avcı gazilerle beraber ağır bir orduyla o asiler ve şakiler fırkasının peşinden giderek çelikten kılıçlarıyla onları yokluk alemine göndermek için benden izin istedi. Halihazırda fetihlerin birçoğu askerlerin çabası olmaksızın yüce yaratıcının bağışıyla gerçekleştiği ve bu şekilde sancağımız yükseldiği için buna izin vermedim.

\section{Yardim Allah'tan geldikten sonra askere ne gerek var}

$\mathrm{Bu}$ arada o taraftan birbiri ardına elçiler geldi; veziriazam Ahmed Paşa'nın beğenilmeyen mektubu ile diğer birçok serhad paşalarının bizim şöhretli ümeramıza yazdıkları mektupları getirdiler. Mektuplarında barış ricacısı olmuşlar, bizim tarafımızdan da barışı görüşecek bir kimsenin sınıra gelmesini talep etmişlerdi. Bundan dolayı mülkün süsü olan meşhur ümera ve ileri gelenler, parlak tedbirli vezirler, din ve devlet evliyasının birçoğu bu durumdan haberdar oldular. Sınırlardaki reayanın çoğu, her iki tarafın atlarının tepelemesinden bıkmış usanmış, katledilmiş ve perişan olmuşlardı. Her iki tarafın ordusunun gidiş gelişinden dolayı birçok yer harap hale gelmişti. Bizim bugün Calut'la ordusuna karşı duracak takatimiz yoktur ${ }^{63}$ feryadını göklere çıkarmışlardı. Her iki taraf da yağma ve talan ateşini atmış; ekini, soyu sopu helak etmek için uğraşır ${ }^{64}$ ayetini Müslümanların mal ve eşyaları için okumuşlardır. Buna dayanarak tekrardan nizamı tesis etmek için Ayas Paşa'nın isteği, veziriazam Ahmed Paşa’nın ricasını dikkate alarak barış hazırlıklarını başlatıp emsallerinin en seçkini Şahkulu Ağa Kurçi'yi bu iş için görevlendirdik. Şöhretli ümeramızdan bazıları, onların mektuplarına cevaben bazı mektuplar kaleme alıp gönderdiler. Felek ihtişamlı bahtiyar evlat Ebulfeth İsmail Mirza, bu ümeraya muhalefet etti; hiçbir şekilde bu durum onun istediği bir şey

61 Kur'an: 4/98.

62 Kur'an: 3/160.

63 Kur'an: 2/249.

64 Kur'an: 2/205. 
değildi. Bizim büyük emirlerimizin yazışmaları o kibirli yalancının eline ulaşınca "Kızılbaş ordusu bizim önümüzde diz çöktü, düştükleri acizlikten dolayı barış talep ettiler” şeklinde yalan haber yayarak bununla herkes içinde iftihar etmek istedi.

O düzenbaz iblisin devletinin bekası ve saltanatının binası hile, yalan ve aldatmacaya dayalıdır. Felek ihtişamlı emirlerimizin mektuplarına cevaben zamanın eteğindeki manzum ve mensur incilerle, ediplerin ve usta münşilerin sözleriyle dolu uzunca belagatli bir mektup yazmışlardı. Gerçekte kendi bidat olan mezheplerini beyan ettiklerinden dolayı ulema ve fuzala zümresi o mektubu anlamaktan aciz düştüler. [Onlara göre] Ebibekr’in lanet ona olsun imamlığı konusunda ileri sürdükleri kesin deliller havas ve avamın nezdinde kabul görmüş. Arapça, Farsça ve Türkçe’den meydana gelen belagatli dilinin aldatıcı ibare ve istiareleri dört mezheplerine gayet uygun, şevk veren manaların tatlılığı ise bütün nükteleri kendinde barındırıyor.

\section{Parlak sayfalara yazılı bir nükte olsa da}

Tamamı senin dörtgen sayfanda mevcuttur

Bu ilgisiz boş ibarelerin ve görülmemiş haşviyatın özeti şuydu: Güya pak elimizi Ehl-i Beyt muhabbetinin 'urvetül-vüskasından çekmedikçe hanedan düşmanlarının yanlış yoluna giremezmişiz. Ebibekr, Osman, Muaviye, Yezîd ve Mervân'a lanet ve ateşler onların üzerine olsun karşı saygılı olmadıkça sözüm ona aramızda barış vücut bulmayacakmış. Sizinle bizim aramızda bir barışın olması zaten imkansızdır. Geçmişte yaşananlar gelecekte de yaşanacaktır. Öyle de yapacağız. Rabbanî dergahtan kovulan, Yezdânî bargahtan uzaklaştırılan, sapkın, Ehl-i Beyt ve seyyidler düşmanı, kinci ve fitneci, peygamber dinini tahrip eden, eşek beyni yemiş korkak, bütün lanetlilerin reisi, bütün dinsizlerin önderi, sapkınlık zaviyesinin münzevisi, elbette kötü bir dössektir ${ }^{65}$ eşiğinin komşusu, şerlilerin serveri, füccarın kıblesi, ateşler yağdıran, dünyayı alıp dini satan, cehennem halkının en büyüğünün en kötü evladı, düzenbazlık ülkesinin yalancısı, iblisin defterinden okuyan, yalanların madeni, küfr ve lanete batmış, iffet ve salahı yok eden, fisk ve mubah geleneğini ihya eden, cahil ve akılsız fâsık, İstanbul puthanesinin baş keşişinden Allahin laneti ona ve bütün mülhit ve münafiklara olsun Muhammed ve onun pak sülalesine yönelik yağmur damlası, ağaç yaprağı, deniz kumu ve nehir suyu mesabesinde zuhur eden bu dağınık ibarelere ve yorumlara, saçma sapan ve cahilce açıklamalara, düzmece iftiralara ve asılsız hikayelere verilecek cevap, o merdîdun sağır kulağına ve o matrûdun çirkin gözlerine ulaştırılacaktır.

65 Kur'an: 2/206. 
"Ahmed Paşa’nın mektuplaşmasından haberim yoktu. Benden habersiz ve izinsiz olarak bu mektubu yazıp sulh meselesini ortaya attı" şeklindeki sözlere cevaben diyebilirim ki eğer dediğiniz doğruysa yani Ahmed Paşa ve diğerleri sizden habersiz, size danışmadan bu işi yaptıysa o zaman bil ki zamanın büyük sultanları ile olan barış meselesi, hilafet ve saltanatın büyük işlerindendir ve bu işin sana danışılmadan yapılması paşanın kendi zayıf tedbirini uygulayarak böyle bir işe bulaştığı anlamına gelir. Paşa, seni zelil ve itibarsız kılarak hıyanetini ortaya koymuş olur. Bu da senin rezilliğine, zelilliğine ve itibarsızlığına yol açar. Eğer kendi isteğiyle böyle bir değişiklik yapmışsa değiştiren Allah'ın lanetine uğrasın. Vasiyeti duyduktan sonra değisstiren olursa şüphe yok ki bu işin vebali ancak değisstirenedir. Muhakkak ki Allah her şeyi duyar ve bilir ${ }^{66}$ Acizlik ve yenilgi halindeyken, çaresizlik ve kıtlık içindeyken daha alçak gönüllü bir şekilde davranarak barış ipine sarılıyorsun ancak aslan tabiatlı savaş meydanı yiğitlerinin ateş saçan kılıçlarından, gazilerin intikam kılıçlarından kurtulunca da mülk kimindir ${ }^{67}$ nidasını aleme atıp, zorbalık ve kibir sancağını yükseltiyorsun. Bil ki biz pak elimizi Mustafa’nın, Murtaza’nın ve onların pak hanedanının şefkat eteğine dolamışı, iman sıfatıyla süslüyüz. Marifetullaha, marifetü’r-Resûl ve marifetü'l-imama gereği gibi uymuşuz. Usul ve füru' bütün şer'i hükümlere gereği gibi uyarak Âl-i 'Abâ ve Eimme-i Hüda'nın muhabbet ve sevgi kemerini De ki Sizden tebliğime karşılık bir ücret istemiyorum, istediğim ancak yakınlarıma sevgidir ${ }^{68}$ doğruluk yolunu gösteren ayetinin hükmüyle can belimize bağlamışız. İlahi hüküm ve Hazret-i Risâlet-penâhînnin fermanı doğrultusunda onların düşmanını ise teberrâ ederiz. Yalanın ve pisliğin madeni, şirk ve mubahın özü, küfrün merkezi, pisliğin mahalli, nifak ve pisliğin toplandığı yer, nübüvvet ve velayet hanedanına olan inatçılığın zuhur ettiği yer olan seninle Allah ve peygamber katında barış yapmak hiçbir şekilde beğenilen bir şey değildir. Hanedanın masumları seninle barış yapıp dostluğu arttırmam konusunda asla razı değillerdir.

\section{Hayat ona haram olası Hâricî ile \\ Sakın tuza bile parmağını uzatma \\ Parmakların beş adet yaratılması ondandir \\ $\hat{A} l-i$ 'Abần eteğinden gayrisina sürme}

66 Kur'an: 2/181.

67 Kur'an: 23/16.

68 Kur'an: 42/23. 
"Biz birkaç defa senin memleketine geldik ve sen bizim karşımızda duramadın. Bize dayanacak gücün yok” şeklindeki boş sözlerinize cevap olarak şunu diyebilirim: Artık şöhretli sultanlar ve zamanın hakanları mertlik ve yiğitlik adını senin için kullanmıyorlar. Seni cihangir sultanlar zümresinden saymıyorlar. Zira bütün hayatın boyunca yiğitlerin, savaşçıların ve kükremiş aslanların safında yer almadın, yiğitlikte bulunmadın. Savaşçı mertler ve yiğitlerle olan savaşlarda hiç sancak kaldırmadın. Yüz bin ok, mızrak, kılıç ve gürz kullanıcısı karşısında kin dolu göğsünü siper etmeyip, sağ kanattan sol kanada, sol kanattan sağ kanada at sürmedin. Aslanların kalbinden ve sağ-sol kanatlarından bihabersin. Hile yapma, kandırma, ateş saçma ve taş fırlatma geleneğine uyarak sürekli etrafı ateşle çeviri kalenin içine girip perde arkasında oturan kadınlar gibi durarak kendini 300 bin namertle çevreler, top arabaları ve zincirlerin ortasında oturursun. Eğer saltanat, şehriyârlık ve yiğitlik iddian varsa pisliklerin ve fâsıkların toplandığı o kalenden erkek gibi dışarı çık ki

Ey mert sıfatlı! Korkuyu aklından çıkar

Kadınlar gibi sürekli bahaneler arama

savaşçı aslanlarımızın, heybetli kaplanlarımızın yiğitlik ve mertliklerini, muzaffer ordumuzun ihtişamını göresin.

\section{Heybette deniz dalgaları gibi ordu}

Sayıda yıldızlar gibi kalabalık bir güruh

Öyle timsahlardır ki senin orduna yönelecek olsalar Elborz Dağı gibi olsalar çelik kılıçlarıyla ve sine delen mızraklarıyla ilk hamlede onları yok ederler. Savaş ateşini yakacak olsalar güneşin altından kubbesini kalpleri diken oklarının ucuyla mavi göklere dikerler. Bilmiş olasın ki yiğitlik ve savaşçlılk bize yüce ecdadımızdan ve ulu babamızdan miras kalmıştır. Eğer buna delil ararsan bütün herkes için şu durum ayan beyan ortadadır: Bizim ilk saltanat ve hilafet tahtına cülusumuzda Turan mülkünün hakanları, Mâveraünnehr, Hıtâ ve Hoten hanları hazret-i Şah Babam'in Allah onun delillerini nurlandırsın beka alemine gidişini firsat bilerek Mâzenderân, Horâsân, Sicistân, Fars, Taberistân, Irak, Azerbaycan ve cennet alametli İran'ın tamamını sahipsiz olduğu gerekçesiyle ele geçirmeyi akıllarından geçirmişlerdi. Ancak şu manadan gafil bir şekilde,

Bu dünyanın düşü̈nlerine hakir gözle bakma

Bilmez misin ki bu toz toprak içinde bir atlı vardir 
ham hayallere düşmüşlerdi. Savaşçılık ve yiğitlikte her biri senin iki katın olan şöhretli seksen padişahın hepsi Amûye Nehri’nden geçerek Horasan memleketine yöneldiler. Biz bu durumdan haberdar değildik. Muzaffer Kızılbaş ordusunun seçkinleriyle 8. İmam Ebu’l-Hasan Ali b. Musa er-Rıza'yı Allab’n salatı, selamı ve senası onun üzerine olsun ziyarete gitmiştik. Ansızın onların gelişinden, belanın varışından haberdar olduk. Mâveraünnehr hanı olan Kücüm Han Turan, Hıtâ, Hoten, Kulmak, Maska, Harezm, Çerâkise ve Deşt-i Kıpçak’ın seksen padişahıyla ve iki yüz elli bin Özbek ve gece vakti karıncanın gözünü oklarılla diken, rüzgar hızına sahip, kan dökücü, deri yüzen Tatarla birlikte idi. Onlardan her biri belki de daha azı yüz kişiyle senin uğursuz orduna karşı koyabilir. Yanımızdaki az sayıdaki askerle Allah'a tevekkül ederek hareket ettik. Mülk otağını ve azametin göklerle boy ölçüşen sancağını gönüllere ferahlık veren bir mekanda açtık. Kadeh çemenzarını kutlu çadırlarımızın kurulduğu mahallere dönüştürdük. 935 senesi Muharrem ayının 10. salı günü [24 Eylül 1528] Özbek, Kulmak ve Çerkes ümerasının, Tatarların şöhretli hakanlarının ve hanlarının orduları bize kavuştu. Sanırsın Nuh tufanı, Hud yıldırımı ve Semud azabı göklerden inmişti. Kös ve surun çığlığı gökleri yırtıyordu. Ordumuzu, halenin dolunayı çevrelemesi gibi çevrelemişlerdi. Yaşça küçük, savaş tecrübesinden ve yeterli asker sayısından yoksun olmamıza, düşmanın ise sayıca üstün olmasına rağmen yaratıcıdan yardım diledik. Nice az bir topluluk Allah'in izniyle çok bir topluluğa galip gelmiştir ${ }^{69}$ manasına yaslanarak kıyametten bir alamet olan o izdihamdan hiç korkmadık. Muzaffer ordunun sağ ve sol kanadını kutlu kardeşlerime bıraktık. Dindar timsahlar ve korkusuzlar, savaşçı kurçiler saflarını oluşturdular. Düşman ordusu tek seferde dört bir yandan ordumuzu ok yağmuruna tutmayı kararlaştırmıştı. Okların çokluğundan gökyüzü öyle bir kaplanmıştı ki

Yaydan ayrılan ok yağma yolunu tuttu
Her köşeden fitneler yükseldi
Tozdan dolayı yerle gök arasında
Yeni bir dünya görünmeye başladı
Zırh her yanda gözünü açtı
Sevgililerin gözü gibi fitne saçtı
O kıyamette mızraklar her yandan
Yiğitleri yermek için dillerini sivriltti
Hayvanların ayaklarından nalları döküldü

69 Kur'an: 2/249. 


\section{Sersemleyerek el ve ayaklarm kaybetti \\ Sivri kulakl kargının gidiş gelişinden \\ Gök adeta çubuk örtüsüyle kaplandr \\ Develerin sırtındaki savaş kösünün narası \\ İki renkli gökteki yıldırım sesiydi sanki}

Tatar askerinin hücumuyla çıkan savaş kargaşası ve çıkan toz duman yüzünden kutlu ordumuz yenildi. Benim kaçtı̆ıı düşüncesiyle askerlerimizden çoğu savaş meydanından kaçmıştı. Her biri bir tarafa yönelmişti. Büyük gazilerden ve Behram intikamlı kurçilerden üç bin kadarı -ki her biri bin kişiyle baş edecek güçteydi- bizimle kaldı. İkindi namazına doğru bir tepeye çıarak iki yüz elli bin kan içici Özbek'in arasına konuşlandık. Muharrem'in 12. günü sabahı bizi yenen bütün Özbek askeri ve Turan memleketleri sultanları harekete geçerek yağma maksadıyla atlarına binmişlerdi. Bu esnada gaybdan gelen haberci On İki İmamlar'ın ve Hazret-i Sahib-zaman'ın Allahin selamı onların üzerine olsun kutsal ruhlarının yardımımıza yetiştiklerini, atlarımıza binmemiz gerektiğini kulağımıza söyledi. Biz de deri yüzen silahlı üç bin adamımızla devlet ve ikbal içinde tepeden aşağıya inip, iki yüz elli bin kan içici Özbek'e hücum ettik. Üç bin kılıç aynı anda kınlarından çekildi. Kılıçla beline vurdukları herkesi taze salatalık gibi ikiye bölüyorlardı. Her kimin başına vuruyorlarsa baştan bele kadar yarıp atıyorlardı.

\section{Killçlar yüzünden miğferler parça parça \\ Çam gibi yere devrildiler \\ Kaçmak için zırhım atan birisi \\ Demirden sıçrayan kıvılcum gibiydi \\ Birbiri ardina helak toprăğna düştüler \\ Birçokları arzularını toprağın altına götürdüler}

Allah'ın inayeti ve güzel yardımıyla üç bin yiğitle seksen Turan mülkü padişahının beraberindeki iki yüz elli bin kişilik orduyu kılıç darbesiyle ortadan kaldırdık. Bir fersah kadar da onları kovaladık. Bir saat içinde o talihsizlerden birkaç binini ateş yağdıran kılıçlarımızla yaktık. Bulduğunuz yerde öldürünüz ${ }^{70}$ kağıdını o talihsizlerin yırtık yakasına astık. Muzaffer ve mansur olarak geri döndük. Özbeklerin sayısız ordusu binlerce ölü bıraktı, geriye kalanlar da kaçtılar. Tarihçiler kitaplarında bunlardan bahsederler. Doğrusu yiğit savaşçlarımız etraf memleketlerde büyük fetihler gerçekleştirdiler. Burada yazılabileceğinden çok daha fazla

70 Kur'an: 2/191. 
fetihler söz konusu oldu. Cümle alem bunu çok iyi bilir. Eğer sen de bizim mertlik ve yiğitliklerimizi görmek istersen kükremiş aslanlar gibi ortaya çık, perde arkasındaki kadınlar gibi oturduğun o ateşten kalenden dışarı gel, o zaman bizim ilahi kudretimizi ve padişahlık haşmetimizi görürsün.

\section{Her kim azmimizin doru atın harekete geçirirse \\ Düşman kılıçlarımızın çı̆̆lı̆̆ından ăglar \\ Burada elçi ve mektup artık is görmez \\ İki yüzlü kuluçtır işi bitirecek olan}

Eğer sen gelmezsen çok yakında ilahi yardımla ve sınırsız faziletle şahlık bargahını İstanbul tahtında kuracak ve Mervânî devlet sancağınızı söküp atacağım.

Yildız ilmini bilenlerin yol göstermesiyle

Rum sultanını tahtına oturayım

Rumîlerin işini bitirdikten sonra

Şahlık adına savaşa hazırlanalim

Eminim ki yeryüzündeki şahlar

Bana hakir kul olacaklar

Bu dünya sadece bir padişablik yerdir

Bu dar yer bir saraylik yerdir

Bizi "seyyidliği ele geçiren” şeklinde takdim etmeniz meselesine gelince: Bu durumun düşmanlıktan, cehaletten, öfke ve fenalıktan kaynaklandığı apaçık ortadadır. Bu olay Kûfe ve Şam halkının, peygamberin ailesine ettikleri zulme ne kadar da benziyor. Savaş gününde şehitlerin seyyidi o korkusuz Yahudilere, o soysuz Hâricîlere "ne sebeple beni öldürmek istiyorsunuz. Allah'a ne cevap vereceksiniz. Sadece Allah’ ın peygamberinin sevgili oğlu değilim belki Murtaza’nın iki gözünün nuruyum da" dedi. Senin rehberin olan o kara yüzlü lanetliler, o sapkın nankörler cevaben şehitler seyyidine "Senin Allah’ın elçisine olan yakınlığın nedir ki” dediler ve onun peygamberle olan yakınlığını reddettiler. Ama sonunda onlardan her biri bir belaya duçar oldular. Din ve peygamberin evladının düşmanlarının, peygamberin evladı ile böyle bir savaş halinde olduğu bir yerde ben kimim ki? Kim benden bahseder ki? Biz senin o boş sözlerinden korkmayız ki. Varsın köpek samanlığın damında havlasın dursun bu hiç sorun değil.

Bütün şöhretli sultan ve hakanlara, cümle aleme aşikardır ki senin ecdadın soysuz ve cahildir. Uzun yıllar boyunca Rumî ve Frengî gulamlarla hemhal olmuş 
ve onu hoşa gidecek bir iş olarak görmüşlerdir. Ondan sonra [Rumî ve Frengî gulamlardan] her birine emirlik ve vekillik mertebesi verip, evlilik yoluyla akrabalık kurmuşlar. Onlardan kız alıp vermişler. İşte senin tohumun bu kabildendir. Hangi mezhepte bu işe izin verilmiştir, sen iyice düşün. Zillet mertebesinde olan hakir birinin önce emirlik gibi büyük bir mertebeye getirilmesi, idare anahtarlarının onun eline verilmesi, daha sonra da cehennemin dibine gönderilmesi olacak iş midir? Osmanlı devletinin kuruluşundan bugüne kadar senin ecdadın ve sülalen hiçbir zaman yüce soylu hanedanlar zümresinden olmadı. Her yerde ve herkesle olan sohbetlerde pak soyluluğu ile herkesten üstün olan bir hanedana karşı yerme ve kötüleme dilini uzatanların alçak ve soysuz olduğuna kuşku yoktur. Yakışmayan sözler söyleyenlerin ve yazanların alacakları cevaplar da olacaktır elbette. Belki de küfürbazlıklarıyla meşhur olacaklardır. Bu dünya, yapılan her şeyin karşılığının alınacağı bir yerdir. Bir dağı düşün ki iyi ve kötü olan her ne varsa ona doğru yüksek sesle söylersen, söylediğin şeyi tekrar duymuş olursun. Biz daha önce memâlik-i mahrûsamızda Teberraîlere ve Kalenderîlere, nebiler serveri ve vasiler seyyidinin hanedanına düşman olanlara açık ve gizli bir şekilde lanetler yağdırmalarını emretmiştik. Bundan böyle seni ve senin tabilerini her yerde, sokaklarda, mescit ve medreselerde, minberlerde Benî Ümeyye, Benî Mervân, Benî Berâmike ve Benî Abbas melunlarının zümresine dahil edeceğiz. Aramızdaki dinî ve mülkî çekişmelere, her iki tarafta yol açtığımız büyük tahribata rağmen sana karşı hep büyük bir saygı ve hürmet besledim; elçilerini karşılamada ve yazışmalarda bir an olsun bu saygımı elden bırakmadım. Sende soyluluk, şeref ve asalet olmadığı, mizacının pislik ve alçaklıkla yoğurulduğu padişahlara yaraşır davranmamandan ve bu şekilde edepsiz boş sözler yazıp göndermenden bellidir. Bundan böyle bil ki mücahitlerimiz olan Teberrâîyan güruhunu Azerbaycan, Horasan ve Irak memleketlerinin mahalle ve sokaklarında yürüterek her yerde sizlere lanetler yağdıracağım. Öyle yapacağız ki Ermeniler ve Yahudiler binek hayvanlarının nallarına senin ve inatçılar güruhunun adını yazsınlar, türlü [hakaretvari] kelimelerle senin zat-1 şerifini ansınlar. Doğrusu ancak senin gibi iyi siretli, hoş görünümlü, pak soylu, seçkin nesepli, övülmüş hanedanlı, yüce ocaklı ve pak mizaçlı birisine yermek ve küfretmek yakışır. Peygamberin evladı, nesep olarak atalarından bu yana yüce mertebeli seyyidlerin en büyüklerinden, alemin en kutlu takva sahiplerinden olageldiler. Yüce soylu, temiz, pak nefisli ve hayır sahibi olmaları, iyi işleri ve güzel sözleri dünyevî saltanata sahip olmada onları öne çıkarmıştır. Yezid ve onun tabileri dünya malına olan tamahlarından ve kendi saltanatını sürdürmek için cennet gençlerinin seyyidi Ebi Abdullah el-Hüseyin'in Allab’ın salatı onun üzerine olsun nesebini kesip atmak, onu helak etmek istedi. Ancak maksatlarına erişemediler. 
Hem bu dünyada hem de ahirette envar cezalara duçar oldular ve oluyorlar. $\mathrm{O}$ kötü itikatlı Hâricî̉nin, kafir soylu o yaşlının, İslam kıyafetinde kendini gösteren, ölümcül hastalıklara müptela olan o ikinci Abdullah b. Ziyâd'ın çeşitli azaplara uğraması en büyük dileğimizdir. Amin ya Rabbü’l-'alemin.

Yüreğin hasret ateşiyle kebap olsun

Fitne rüzgariyla uğursuz evin harap olsun

Senin varlik dünyanda ey fesat kalpli

Ordun mihnette olsun, üzengilerinde gam yükü

Ömrünün gül bahçesi zulüm rüzgaryyla solsun

Felek sana sonsuz zulmünü yağdırsin

"Bağdad'ı ve bilmem daha nereleri tasarrufumuz altına aldık, kafirlere karşı gaza ve cihat eyledik" sözlerinize cevap olarak şu denilebilir: Herkes de çok iyi bilir ki Bağdad Tekelülerin tasarrufundaydı. Onlardan bazı hıyanetler ortaya çıkınca [Tekelülere] artık güven kalmadı. Dinlenmesi gereken emrimiz üzerinde Şerefeddinoğlu Bağdad'ı bırakıp dergahımıza yöneldi. Yoksa gazilerimizin kılıçlarından arta kalan senin yenik ordunun ne haddine ki Bağdad'ı çevrelesinler. Van Kalesi'nin ele geçirilmesi, Çepni taifesinin namertliği, dönek Ulama’nın hileleri ve kalenin teslim edilmesi herkesin malumudur.

Yemen ve San'a konusunda yazdıklarına gelince; Yemen hakiminin elçileri bizim yüce dergahımıza gelip bu fethin ne şekilde gerçekleştiğini uzun uzadıya arz ettiler. Bu fethin de hilelerle gerçekleştiğini böylece bilmiş olduk. Yemen hakimi sana karşı mertçe savaşmış, [seni] yenerek kaçırtmıştı. Ancak Yemen ülkesinin bir kısım topraklarını boş bulunca geri dönüp, deniz kıyısındaki bazı yerleri tasarruf altına aldınız. Kaleleri muhkem hale getirip Yemen’in bir kısmını hileyle ele geçirdiniz. Biz de eşsiz kaleleriyle, sağlamlı̆̆ıla bilinen, hazinelerinin çokluğuyla dünyanın en iyi mülkü mesabesinde olan, bütün her yerden tacirlerin akın akın geldiği şöhretli şahların tasarrufundaki Şirvan'ı çelikten kılıçlarımızla ele geçirdik, hile ve yalanlarla değil. $\mathrm{O}$ mülkü etrafiyla beraber ele geçirerek minberleri, aman vermez kılıçlarımızla din düşmanlarının pisliklerinden temizleyip Eimme-i Ma’sumîn Allahin salatı onların üzerine olsun adına okuttuğumuz hutbeyle süsledik. Bu yeni fetihlerimizden birisi Şeki'nin fethidir. Oranın valisi atalarından bu yana gönüllere ferahlık veren bir yerde, Hayber gibi kalelerde yaşıyordu. Kaleler yıkan toplarımızla ve tüfeklerimizle kalelerini yerle bir ettik. Çelikten kılıçlarımızla o kara bahtlıyı kırdık geçirdik. O civardaki bazı Gürcistan beldelerinin kalelerini yıktık. Dini akideleri kabul ederek mezheb-i hakkın doğru yolunu tuttular ve şimdi bu saadetle 
övünüyorlar. Keşiş ve ruhbanlarından birkaç binini köpekler gibi öldürdük, bütün manastır ve puthanelerini viran ettik. Bütün ümeramız her yıl kafirlere karşı gazayla meşgul olurlar. Hâricîlerin askerleriyle, mülhitlerin ordusuyla savaşı bitirdikleri anda cihad-ı ekberden cihad-ı asgara yönelirler ve böylece yeni bir fetih ortaya çıkar. Emâret-penâh, nısfet-destgâh, 'umdetü'd-devleti'l-kâhire, rüknü’s-saltanati'l-bâhire, dergâh-ı gîtî-penâhın havâssı zümresinden Muhammed Han Şerefeddinoğlu -ki Horasan memleketlerinin merkezi mesabesindeki Herat, evvelki sultanların ele geçirme arzusu taşıdıkları yeryüzündeki o cennet onun idaresi altındaydı- mertliği ve yiğitliğiyle hareket ederek bütün Gur ve Garcistan vilayetini tahrip etti. Oranın bütün kaleleri sağlamlığı ile şöhret bulmuştur. Genişliği ve havasının güzelliği ile Yemen ve San'a'yı aratmaz. O geniş memleketin serdarları kırk adettir. Yirmi bin okçu savaş zamanında toplanırlar. Oraların sultanlarından hiçbiri asla hiçbir hakan ve sultana itaat etmemiştir. Zamanın hakanlarından hiçbirisi orayı ele geçirememişti. Dağlarının zirvesi göklere değiyor, kaleleri göklerle boy ölçüşüyor. Hayat suyu oranın nehirlerinde akıyor, İsa nefesini oranın havasının güzelliğin almış. [Bütün bu yerleri] kutlu gazilerin, intikam ormanı aslanlarının kılıcıyla devlet-i kahirenin evliyasının tasarrufu altına aldık. Oranın bütün halkı ehl-i imanın şiarından ve hak mezhebinden nasipsizdi ve bütün ömrünü sapkınlık yolunun karanlık çöllerinde geçirmişlerdi. Allah’ın yardımıyla eteklerine bulaşmıs olan pislikleri temizledik. Gayb aleminin habercileri ve beşaret yolunun rehberleri, Ehl-i Beyt'im Nub'un gemisi gibidir müjdesini onların kulaklarına ulaştırdı. Keder dolu karanlık geceler gibi olan yüreklerinin sayfaları, Ehl-i Beyt muhabbetinin doğan gününün müjdesiyle nur üzerine nurdur ${ }^{71}$ sayfalarıyla parladı ve hayat buldu. Allahü Teala'nın buyurduğu gibi Allah kimi doğru yola götürmek isterse İslamı kabul etmesi için gönlünü açar. ${ }^{72}$

Bu günlerde o taifeden yüz bine yakın aile Haydar-1 Kerrâr'ın muhabbet ve Ehl-i Beyt-i Seyyid-i Muhtar'ın imamlık kemerini can beline bağlayıp bizimle ittifak edip, alemlerin sığınağı olan dergahımıza hediyeler gönderdiler. Verdiği nimetler için Allah'a hamdolsun.

"Resulullah'ın halifesi ümmetin icma’sıla Ebubekr b. Ebi Kuhâfe'dir" lanet onun üzerine olsun şeklindeki mezhep ve itikat konusunda yazdıklarınıza cevap şudur: Bil ki iftira atan kimse ehl-i iman dairesinin dişındadır. Allab’n ayetleri-

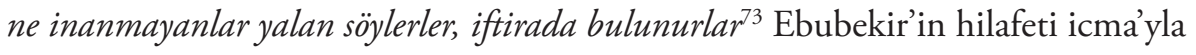

71 Kur'an: 24/35.

72 Kur'an: 6/125.

73 Kur'an: 16/105. 
oldu diyen kimse bütün ümmetin onun halifeliği için onay verdiğine inanyyor mu? Cümle alem çok iyi bilir ki bunun hiçbir doğruluğu yoktur. Çünkü birkaç inatçı fesat kimsenin dışında bir şehrin hatta bir mahallenin ahalisi bile onunla ittifak etmedi. Eğer ümmetin havâssıyla icma’ olunduğuna inanıyorsa o zaman bütün Müslümanların ittifakıyla Ali b. Ebi Talib’in (a.s.), İmam Hasan ve İmam Hüseyin'in selam onların üzerine olsun Abbas ve Abdullah Abbas'ın, Talha ve Zübeyr'in, Selman ve Ebuzer'in, Mikdâd ve 'Ammâr'ın, Abdullah b. Mes'ud ve Ebu Eyyüb Ensârî̀nin, Ebi Ke’b ve Mâlik Eşter'in ve Mâlik b. Züheyr'in kendi kabilesinden on bin kişiyle, Sa'd b. 'Ubâde'nin, Kays b. Sa'd Hazrec kabilesinden on bin kişiyle ona muhalefet etmelerine ve biat etmemelerine ne demeli? Bunlar sizin bütün kitaplarınızda da yazılmıştır. Mübarek isimleri zikredilen bu bütün ümmet, Müslümanlar, Ehl-i Beyt büyükleri, sahabenin ileri gelenleri ve ümmetin seçkinleri mi bu ittifakın içindeydi? Adları zikredilen bu topluluk defalarca Ebibekir'e lanet onun üzerine olsun karşı çıktılar. Ona karşı hüccetler topladılar. Bu işten vazgeçirmeye zorladılar. Bu topluluğun korkusundan iş yapma kudreti kalmadı. Ne seçkinler zümresinin desteğini alabildi ne de bütün ümmetin desteğini. Bir karar için toplanıldığında Kur'an nasları ve peygamberin hadislerinin aksine karar alınırsa batıl olmuş olur. Hz. Ali b. Ebi Tâlib’in imamlığına dair Kur'an ayetleri vardır, peygamberin ise sayısız hadisleri. Aklî ve naklî deliller o kadar çok yazıldı ki demek ki hiçbiri senin ve ulemanın gözüne çalınmamış.

Bil ki geçmişte Allah’ın hiçbir peygamberinin kırk yıl putperestlikte geçiren, puta köle olan, edepsizlik ve zorbalık kemerini can beline kuşanan ve ondan sonra halife ve vasi olan hiç halife ve vasisi olmadı. Adem-i Safî nin yaratılışının başından Hatem-i Enbiyầya kadar Allahin selamı ona ve ailesine olsun dünyadan göçen her bir peygamber için Allah'ın bir vasi ve halife tayin etmesi muayyen bir hal almıştı. Nebi'nin vasisi de Allah tarafından seçilmişti. Hiçbir zaman nebinin, ilahi karar olmadan vasi tayin etmesi ya da ümmetin Allah'ın ve peygamberin rızası olmaksızın vasi belirlemesi şeklinde bir gelenek olmadı. Beka alemine göçen hiçbir nebi yoktur ki kendisine bir vasi ve halife tayin edilmemiş olsun ve onun ümmeti de perişan kalmış olsun. Peygamberin sahip olduğu mucize, ismet, taharet, ilm ve şecaat sıfatlarının tamamına vasileri de sahiptiler. Hiç kimse bunu inkar edemez. Enbiyânın seyyidi, peygamberlerin en üstünü ve en iyi yaratılmıs olan peygamberimizin vasisi ve halifesinin de bütün vasi ve nebilerden daha üstün olması, enfüsina ve enfüsikum ve min indillah ve indi resullullah hükmüyle tayin edilmiş olması gerekir. Eğer basiret gözüyle bakacak olursan olmasaydın gökleri yaratmazdım lafzı, faziletinden bir alamet olan alemin seyyidi, Hatem-i Enbiyâ içindir. Allah'ın onun 
için bir vasi ve halife tayin etmemiş olması mümkün müdür? Elçinin dinini sahipsiz bırakarak ve ümmetini başıboş bırakarak kendi yerine bir vasi ve halife tayin etmemiş olması düşünülebilir mi? Bütün ümmetine vasiyetini beyan etsin ve kendisi vasisiz olarak beka alemine yönelsin? O kadar cahilsin ki sırf sapkınlık ve düşmanlıklarından halk arasına boş sözler yayan, eşek beyni yemiş bir kaç kişinin sözüne inanıyorsun. Onlar ki ne tarih ne de tefsir kitabı görmüşler. Ne haberler ne de rivayetler onlara ulaşmıştır. Ne de sayısız olan kelam kitaplarını mütalaa etmişlerdir. Onların çoğu takip ettikleri babaları ve hocalarının yerine geçmişlerdir. Biz atalarımızı bir yol üzerinde bulduk ve onların ögretilerini izliyoruz ${ }^{74}$ ayeti onlar için nazil olmuştur. Vasilerin seyyidi, takva sahiplerinin serveri, la feta meydanının şehsüvârı, Hazret-i Mustafa' nın can kardeşi, Emîrü’l-Müminîn, imamü’l-muttakîn, kâid-i 'izzü'l-muhaccelîn, halifetullah ve resuluhu fi'l-'alemîn, Ebu'l-Hasaneyn Ali ibn Ebi Talib'in Allabin salat ve selamı onun üzerine olsun -ki beni kaybetmeden önce bana sorular sorun, göklerin altında olan şeyler hakkında bana sorun, lafzı onun sonsuz ilminin, perde aradan kalksa dahi hiçbir şey benim yakînime eklenmez doğru sözü bilgi ve zekasının ulaştığı noktadır- azamet vesikasına azl tuğrasını çekmişlerdir. Göklere ve yerlere, avama ve havassa, yerli ve yabancıya, bütün Yahudi ve Hıristiyan'a malumdur ki Hz. Risâlet-penâh Allah'in salat ve selamı onun ve ailesinin üzerine olsun vasisi, halifesi, kardeşi ve amcasının oğlu olan Hz. Ali'yi ey Resul sana indirileni teblĭg et, ĕger bunu yapmazsan onun peygamberliğini yapmamıs olursun Allah seni insanlardan korur ${ }^{75}$ hükmü gereğince Allah' in emriyle kendi yerine vekil tayin ettiğinde ömrünün son zamanlarındaydı. O hazretin helal ve haramı beyan etmede hiç kimseden korkusu yoktu. Çünkü halkın tamamı orada hazır bulunuyordu. Yegâne korku Ali b. Ebi Tâlib’in imamlığının sonuçlanmasıydı. O hazretin, sahabeden ve gayriden nifak sıfatına sahip olan düşmanlarının çokluğundan, o hayır sahibi serverin zülfikârının korkusundan boyun eğmiş gibi görünüyorlardı. Çoğunun babası, amcası ve dayısı o hazretin elinden azap şerbetini içerek ölmüştü. Zira onlarda iman sıfatı yoktu, kalpleri nifakla dolu idi. Enbiyanın seyyidi de onlardan korkuyordu. Allah seni insanlardan korur ayeti bu sebepten nazil olmuştu. Bu sizin birçok tefsir kitabınızda da yazılmıştır, bütün tarih kitaplarında da vardır. Allah’ın elçisinin ölümünden sonra yaşananlar kitaplara yansımıştır ki onların her biri bu âlemde meşhurdur. Bu kitaplar sizin değersiz nazarınıza ulaşmamıştır. "Sizin dostunuz (veliniz) ancak Allah'tır, Resulüdür, iman edenlerdir; onlar ki Allab’in emirlerine boyun eğerek namazı kılar, zekâtı verirler ${ }^{76}$ ayeti ehl-i İslamın

74 Kur'an: 43/22.

75 Kur'an: 5/67.

76 Kur'an: 5/55. 
da ittifak ettiği gibi Murtaza Ali için nazil olmuştur. Bütün âlemin hâkimi Allah ve onun elçisidir. Ali b. Ebi Tâlib de hâkimdir. Cümle halka hükmetme seçkinliğine sahip olup de ki Geliniz, sizler ve bizler de dâhil olmak üzere, siz kendi çocuklarınzı biz de kendi çocuklarımızı, siz kendi kadınlarınız, biz de kendi kadınlarımızı çağıralım, sonra da dua edelim de Allah'tan yalancılar üzerine lânet dileyelim ${ }^{77}$ ayetinin manaları bunun şahidi ve destekleyicisidir. Yüce Allah, Ali b. Ebi Tâlib’i Resul'ün nefsi olarak adlandırmıştır. Kimsenin bu konuda itirazı yok ve buna dair batıl yorum yapmazlar da. Harun Musa'dan olduğu gibi sen de bendensin, Ehl-i Beyt'im Nuh'un gemisi gibidir, kim ona binerse kurtulur, kim uzak durursa boğulup helak olur ve aynı şekilde ben ilmin şehriyim Ali de kapısı, ben ve Ali aynı nurdanız gibi hadislerin doğruluğu konusunda bütün ehl-i tevaifin icma'sı vardır ve hiç kimse buna muhalefet etmemiştir. Yine ben kimin mevlâsı isem Ali de onun mevlâsıdır. Allahım onu seveni sev, ona düşman olana düşman ol doğru kelamı Herat şeyhülislamının, Emîr Ali Şîr [Nevâî] adına kaleme aldığı mufassal risalesinde nakledilir. Şevâhidün-Nübüvve ve Ravzatü'l-Abbâb'da Gadîr günü detaylı olarak anlatılır. Allah'ın Resul'ünün dar-1 fenadan dar-1 bekaya göçü esnasında ümmete "size iki şey bırakıyorum, Kur'an ve Ehl-i Beyt'im. Onlara sarılıp uydukça yolunuzu hiç şaşırmazsınız. Bana havuzda ulaşana kadar birbirlerinden asla ayrlmayacaklardır" şeklinde vasiyet ettiği sizin bütün hadis kitaplarınızda zikredilir. Aynı şekilde Ey Ehl-i Beyt! Allah sizden, sadece günahı gidermek ve sizi tertemiz yapmak istiyor ${ }^{78}$ ayeti onlar için nazil olmuştur. Allahü Teala onların masumiyet ve temizliği için şahadet getirdi ve onları bütün kirlilikten pir ü pak kıldı. Onları sevmeyi hükmetti: De ki Ben buna karşılık sizden akrabalık sevgisinden başka bir ücret istemiyorum. ${ }^{79}$ Onlar1 selam İbrahim’in sülalesi üzerine olsun selamıla mümtaz kıldı. Yüce yaratıcı sizin imamlarınızın cahilliği ve akılsızlığı hususunda şahittir. Sizin kitaplarınızda zikredilmiştir ki Ebibekir ve Ömer lanet o ikisi üzerine olsun Allah'ın Resul'ünün mübarek odasında oturmuşlardı. O esnada Ebu Rekeb b. Mülcem gelmişti. Ebubekir, Resul'e "Akra b. Habis'i Temîm emîri yap" dedi. Ömer de bir başkası için ricada bulundu. Ardından Ebubekir sesini yükselterek "senin maksadın bana muhalefetten başka bir şey değildir” dedi. Ömer de bu şekilde sözler söyledi. Onlar Resul'ün huzurunda böyle edepsizlik yaparak seslerini yükselttiklerinden o saat Sana odaların arka tarafindan bă̆ıranların çoğu aklı ermez kimselerdir ${ }^{80}$ ayeti nazil oldu. Bu

77 Kur'an: 3-61.

78 Kur'an: 33/33.

79 Kur'an: 42/23.

80 Kur'an: 49/4. 
olay sizin kitaplarda yazılmıştır. Biz sizin kitaplarınızda düşmanlara lanet okumanın bütün gerekçelerini ve Ehl-i Beyt'in faziletlerini de bulduk. Muhammed Haydar'ın telif ettiği sizin Cem' beyne’s-Sıhâh kitabınızda Câbir b. Semere'nin şu hadisi naklettiği yazılmıştır: Resulullah buyurdu ki 12 Imamlar'in hepsi de Kureyş̇tendir. Aynı şekilde sizin tefsir kitaplarınızda peygamberin mağaraya yöneldiği, Hz. Ali'nin onun yatağına yattığı ve canını ona feda ettiği yazılmıştır. Allahü Teala bütün meleklerine Ali b. Ebi Tâlib’in yiğitliğini ve canını Resul'ün yoluna feda etmesini övünce bu ayet nazil oldu: Insanlardan öyleleri de var ki Allabin rizasin almak için kendini ve malını feda eder. ${ }^{81}$ Aynı şekilde Onlar verdikleri sözleri yerine getirirler $^{82}$ ayeti de Ali b. Ebi Tâlib için indi, bir başkası için değil. Yine Allah'ın Resul'ü, Hz. Ali'nin bir tek kılıç darbesini üns ve cinin bütün amellerine denk tutmuştu. Bu menkıbelerin hepsi de sizin tarih ve tefsir kitaplarınızda yazılmıştır. Ama sizin bundan haberiniz yok. Bunlar o hazretin menkıbe denizinden ve fazilet okyanusundan sadece bir damladır. Ve sen dergâhın reddedilmişi, Allah'ın Resûlü’ne muhalefet ederek alçak hasletlerin ve kötü fiillerinle vasilerin serverinin vesayet, imamet ve hilafetini yeriyorsun. Nebînin risâletine dil uzatman, yaratıcının tekliği konusunda şüpheye düşmen olur mu? Eğer bunlar olmayacaksa pekala neden ilahi hükme ve peygamberin nassına muhalefet ederek peygamberin bütün kemâlât ve faziletini kendinde taşıyan Allah'ın Resul'ünün kardeşini ve amcası oğlunu Ehl-i Sünnet'in naklettiği şu hadisin de hükmettiği gibi “kim Âdem’in ameline, Nuh'un takvasina, İbrahim'in huyuna, Musa'nın heybetine, Isa'nın münacatına bakmak isterse Ali b. Ebi Tâlib'e baksın" velayet ve vesayetten azl ediyorsun ve diyorsun ki ümmetin en zelili olan kirbas $^{83}$ satıcısı Ebibekr, Resul'ün imamı, halifesi ve vasisidir. Hâşấ! Bu, çok büyük bir iftiradır ${ }^{84}$ Allah' ın laneti size olsun ki ilminizin ulaştığı yer cehalettir, onun aslı da küfrün en dip noktasıdır. Bu tür ibareler Allah'1 zulümle -zulüm bir şeyi kendi yerine koymamak, onu alıp başka bir yere koymaktır-bağdaştırmaktan başka bir şey değildir. Vasilerin seyyidi Ali b. Ebi Tâlib’in, vesayet ve hilafet mertebesi yoksa o zaman neden Allahü Teala velayet makamını [belirlediği dışında] orada başkası olamayacak olan şeklinde tayin etti, belirlediği dışında olacak olan diğerlerini tanımadı ve dedi ki Sizin dostunuz (veliniz) ancak Allah'tır, Resulüdür, iman edenlerdir; onlar ki Allab’n emirlerine boyun ĕgerek namazı kılar. ${ }^{85}$ Gadîrhum Bayramı gününde Resul'ün buyurduğu gibi onun fazilet,

81 Kur'an: 2/207.

82 Kur'an: $76 / 7$.

83 Kumaş, keten veya pamuk bez.

84 Kur'an: 24/16.

85 Kur'an: 5/55. 
kemâlât ve masumiyet marifetine sahip olmayan kimse imamet mertebesine layık olamaz. Ardından amcasının oğlunun elini tutup otuz üç bin sahabe ve binlerce insan arasında minbere götürerek elini kaldırmış ve ona dua etmişti, onun düşmanlarına da lanet. Allah'ım onu seveni sev, ona düsman olana düsman ol. Ona yardım edene yardım et, yalnız bırakanı sen de yalnız bırak. Allah'a ve Resul'üne aşikâr olmayan şey nasıl olur da Ömer b. Hattâb'a, Ebu 'Ubeyde b. Cerrâh'a, Salim Mevlâ Benî Huzeyfe'ye ve diğer birkaç münafığa ayan olur. Onlar Ebibekir'in, Sakife-i Benî Sa ide'de kendi iddialarının peşine giderek Allah'ın Resul'ünün tekfin ve teçhizinin gerçekleştirilmesinde bulunmadığını ve riyaset ve hilafet davası güttüğünü, Ali b. Ebi Tâlib yerine Ebubekir b. Ebi Kuhâfe'yi kılıç zoruyla öne çıkarıp "elini uzat da sana biat edelim. Zira sen en yaşlımız ve en ileri gelenimizsin" dediklerini biliyorlar mıdı? Ebubekir'in imamlığının kat'i delillerinden bir olarak öne sürüp beğenilmemiş mektuplarında ifade ettikleri bir diğer şey de şuydu: "Eğer Ali b. Ebi Tâlib, Ebubekir’i imamet ve hilafete layık görmediyse neden onu engellememiş, yakalayıp onu def etmemiş" O hazret sahip olduğu bütün kuvvet, kudret ve şecaatle Haydarî serpençesiyle Hayber' in kapısını yerinden söküp attı. 'Amr ve 'Anter' in başlarını gövdesinden ayırdı. Hayber'in üç bin man ağırlığındaki kapısını elinin üzerine alıp suyun üzerinde durarak Müslümanların onun üzerinden geçmelerini sağladı. 'Amr b. 'Adûd'u tek kılıç darbesiyle öldürdü. Allah'ın Resul'ü Alinin Hendek Savaşındaki bir tek kılıç darbesi, tüm Müslümanların kıyamet gününe kadar yapacaklar ibadetlerden üstündür buyurdu. Benî Haşim kabilesinin tüm fertleri bu muharebelerde Ali'ye tabi olmuşlardı. Ali'nin katıldığ bütün bu savaşlarda Ebubekir zayıf, güçsüz ve yardımsız idi. Peki o zaman neden Ali Ebubekir’i bu işten men etmedi ve kendi hakkının alınmasına razı oldu? Hazretin fesahatla dolu kelamından ibaret olan, yaratıcının kelamının altında, yaratılmışların kelamının üstünde olan, Ehl-i Sünnet ve Cemaat'ten birçoklarının üzerine şerhler yazdığı, hutbelerini ondan seçtikleri Nehcül-Belăga kalbi kör olan o cahilin nazarına ilişmedi mi ki o hazret o kitapta buyuruyor ki Muhammed'in vasiyeti olmasayd yeryüzünde Allah'a karşı kâfir, Resul'üne karşı münafik ve Allah dinini inkâr edenlerden bir tekini bile burakmazdim. Lakin ben sadece gam ve kederimi Allah'a arz ediyorum. ${ }^{86}$ Kitabın bir başka yerindeki ifadelerin muhatabı Ömer b. Hattâb hak ettiğini bulsun idi. Hz. Ali, ona şöyle demişti: Ya İbn Dahhak! Eğer Allah tarafindan önceden verilmiş bir hüküm olmasaydı ve peygamberin ahdi öne çıkmasaydı sana zayıfın nasıl galip geldiğini az sayıda olanın nasıl çoğaldı̆̆ını gösterirdim. O soysuz zalimlerin zulüm ve sitemlerinden bahseden Şakşakiye Hutbesi ve diğer

86 Kur'an: 12/86. 
şikayetlerin o hayır sahibi seyidin mucizeler beyan eden dilinde cari olduğunu görmemiş, duymamışlar. Nehcül-Belă̆a mütalaa edilmelidir. O hazretin bir başka yerde buyurduğu sözleri anlama karşısında dünyanın bütün fesahat erbabı acze düşmüşlerdir: İlahi emr ve peygamberin vasiyeti [peygamberden] sonra Nakısin, Kastin ve Markin'deki savaşlar hariç kılıcımı kınından çıkarmamamı telkin etmişti. Bana dedi ki "ya Ali! Benden sonra sana birçok mekruh rast gelecek. Sana zulüm edecek olan bir kısım ashabıma şefaatim erişmeyecek. Mazlum olan sen bana ulaşacaksın." Dedim ki "benim öldürülmemden korkuyor musun ki beni onlar bertaraf emekten men ediyorsun?” Dedi ki “ya Ali! Yüce yaratıcı bana dedi ki Ë̆er sen kılıcını çekersen seninle savaşırlar. Benî Haşim'den olan tabilerin ve az sayıdaki büyük ashabın sayıca azdırlar. Onlar senin adamlarn öldürürler ve böylece İlam bertaraf olmuş olur. Kur'an ve hadis yok olur. Eğer muradina ermek istiyorsan sabredersen çok daha iyi olur." Bu ibareler Nehcü̉l-Belăga'da açıkça geçer. Allah'ın elçisinin ölümünden sonra sizin imamlarınız olan o din düşmanları ve mürted taifenin Haydar-1 Kerrâr'a ve Seyyid-i Muhtâr'ın Ehl-i Beyt'ine yaptığı fesatlar cümle âlemin malumudur ve bütün tarih kitaplarında yazılıdır. Öyle görünüyor ki sen cahilin sağır kulağına ulaşmamış. Dinsiz âlimler ve nüfuz sahibi cahiller senden gizlemişler. İmamet konusundaki gazapları, Fedek'i almaları, Emîrül-Müminîn'e kılıç çekmeleri, kapıyı tekmelemeleri, Hazret-i Seyyidetü’n-Nisâ Fatima-i Zehrâya Allah’n salâtı onun üzerine olsun yapılan açık zulümler, sizin tecavüzkar Ayşe'nizin yaptıkları, o üç zalim ve gaddarın tabilerinden ve sapkın ve melun Muaviye ve onun Benî Ümeyye'den evlad ve ashabından ve Abbasi taifesinden zuhur edenler, Emîrü’l-Müminîn Ali b. Ebi Tâlib ile olan savaşlar, Resul'ün ashabının helahi ${ }^{B 7}$ zehriyle katledilmesi, Kerbela Savaşı ve şehitler seyyidinin Ehl-i Beyt'ten ve onun ashabından yetmiş iki yoldaşıyla katledilmesi, Ehl-i Beyt'in yağmalanması, Resul'ün Medine'sinin yağmalanması, büyük ashabın katledilmesi, Allah'ın evinin tahrip edilmesi, Kâbe'yi mancınıkla vurma, Allah'ın hariminin yağmalanması, geri kalan masum imamların Allab’n salatı onların üzerine olsun katledilmesi, binlerce dindar müminin ve Haydar-1 Kerrâr takipçilerinin/şiîlerinin öldürülmeleri gibi korkunç olaylar Al-i Muhammed'e zulmedenlerden ve Ehl-i Beyt'in katillerinden sizin önder ve imamlarınız olan Benî Ümeyye ve Benî Abbas' ın gerçekleştirdiklerinden sadece az bir kısmıdır. Şimdi sen de o kâfirlerin uğursuz geleneklerini sürdürdüğüne göre onlarla haşr olacaksın. İmamı, Allah'ın elçisinin can kardeşi ile savaşan, peygamberin oğlunun başını kesen, peygamberin Ehl-i Beyt'ini esir eden bir kimsenin küfründe şüphe yoktur. Sizin bidat nev'inden delillerinizin hepsi bu minvaldedir. Dindar, mümin bir fazıl

87 Panzehiri olmayan kuvvetli zehir. 
kimseye [doğrular konusunda] asla hiçbir diyarda konuşma firsatı vermediler. Ağızlarını açmalarına izin vermediler. Bu taife gerçekte çok meşhurdurlar. Gördükleri ve duydukları her yerde öldürdüler. Bu taifeye ait her nerede kitaplar buldularsa bakmaksızın yaktılar. Herkesten gizlediler. Benî Ümeyye, Benî Mervân ve Benî Abbas zamanlarından kitap nakilleri yaptılar. Filan, filanın ittifakıyla halife, filan da emir oldu, filan ve filan imamette ittifak etti şeklindeki efsun ve efsanelerle dolu saçmalıklarla dar görüşlülerin gözlerini kapattılar. Doğrusu insanların en faziletlileridir. Bu asılsız hikayeleri ve boş rivayetleri risâlet, nübüvvet, ismet, taharet, ebrâr-1 melaike, tahkik ve hakâik ilminde hüccet kabul ettiler. Ardından bunları halkın diline düşürdüler. İnsanları Allah'ı, Resul'ü ve İmam'ı tanımaktan yüz bin ferseng uzağa attılar. Karanlıklar, karanlıklar üzerine yığ̊lmıştır ${ }^{88} \mathrm{da}$ hapsettiler. Sizin hikaye ve rivayetlerinizin çoğu Ehl-i Beyt'e zulmedenlerden, onların en fesat ve en kafir katillerinden nakledilmiştir. Hadislerinizin çoğu yalancı fâsıklardan, serçelerle oynayan küçük çocukların ağzından nakledilmiştir. Fâsıkların, füccârların, kadın ve çocukların adlarını hadis ve ahbâr rivayeti silsilesinde göstermişlerdir. "Filan şunu dedi, filan bunu söyledi" sözlerini insanların dillerine pelesenk ettiler. Filan hadis, filan şeyhe söylenmiş, filan şeyh rivayet eder ki filan şeyh velayetiyle muhaddistir, filan cahil şeyh Kur'an müfessiridir, filan basiretsiz cahil filan zaviyede birkaç erba'in sahibidir ve zamanın büyük evliyasındandır, filan şeyh rüyasında şöyle görmüş, peygamberden şunları duymuş. Bu gibi şeyleri basiretsiz cahiller, marifetsiz aptallar, cehalet zaviyesinin ahmakları, sapkınlık sahrasının şeytanları şehir ve beldelerin her tarafında nakl ve rivayet ederler. Marifet, şeriat ve tarikat binasını uyku ve hayale yasladılar; bu nakil ve nakilcilere bel bağladılar. Bu boş sözler avamın, senin cahil aptallarının ve senin tabilerinin muhayyilesinde yer kaplamış. Tabiler ve takipçiler bu yerilesi yöntemle ortaya çıktılar ve çıkacaklardır da. Resul'ün Ehl-i Beyt'ine, evladına, takipçilerine ve şî̂lerine olan kin ve düşmanlığı miras almışlar ve onların izledikleri yola muhalefet etmişlerdir ve edeceksiniz de. Putperestlikle, şarap içmekle, Müslümanların haksız yere kanını dökmekle ve mallarını gasp etmekle ömürlerini geçiren Âl-i Muhammed düşmanları, oğlancılık marazına müptela idiler. Sizin Sahîh-i Buhârînizde de bahsedildiği gibi Ömer $b$. Hattâbin sahip olduğu bir oğlanı vardı ve hilafetinde onun için bir sorun yaratmıyor$d u$. Bu taifeyi, hanedanın masumlarından daha mı önde tutuyorsunuz? Fâsıkların nakillerini itibarlı mı görüyorsunuz? İş öyle bir dereceye varmış ki Emîrü'lMüminîn, Seyyidetü’n-Nisâ, İmam Hasan ve İmam Hüseyin ve diğer masum imamlar Allab’n salatı onların üzerine olsun -ki onlar herkesin ittifak ettiği gibi

88 Kur'an: 24/40. 
masum ve temizdirler- ile ilgili rivayet nakillerini onların düşmanlarından ve ahbabından yapmışlardır. Bütün zamanlarını Resul'ün hizmetinde geçiren, o hazretin her şeyine vakıf olan bu taifenin sözlerine ve yaptıklarına itibar etmiyorlar. Onların hadis nakline itimat etmiyorlar. Onların mezheplerinin temeli tecavüzkar Ayşe'nin, baras hastalığına müptela Enes b. Mâlik'in, kovulmuş Ebi Hureyre'nin, melun 'Amr b. As'ın dinsiz kafir Muaviye'nin ve onların ashabının hadis ve rivayet nakillerine dayanır. Bunlardan her biri zamanının en kötüleri ve en aşağılıklarıdır; bütün kafirlerden bile daha aşağılıklardır. Onları lanetlemek herkesin görevidir.

Bu esnada sizin kara yüzlü, sapkın ve cahil bilgin ve fazıllarınız işte onlara Allah lanet eder ve lanet ediciler de onlara lanet eder ${ }^{89}$ dünyevî heveslerini, öbür dünya sarayına kendi rızalarını ise Allah'ın rızasına üstün tuttular. Kendi yalan sözlerini ortaya çıkarılmış hadislerle sağlamlaştırdılar. Bu Taife-i Nâcîye-i Kızılbaş ise iman sıfatına sahiptir. Marifetullahı, marifetü’r-Resul ve marifetü'l-İmamı hasıl etmişlerdir. Kıyamet gününe, peygamberin getirdiği bütün her şeye itikatları vardır. Bütün işlerinde nebevî şeriata uyarlar. Namaz, oruç, hums, zekat, hac ve cihâd gibi şer'î yükümlülükleri yerine getirirler. Sizin bidat olan mezhebinizde mubah olan şarap içmek, haksız yere kan dökmek, zina ve livata gibi yasaklanmış şeyleri haram bilirler. Sonsuz devletimiz zamanında bütün bunlardan kaçınmışlardır. Takva ve taharet sahibidirler. Mümin ve müslümanların kanını ve malını helal görmezler. Sırtlan ve tavşan etini yemezler. Def, çeng, ney, rübab, tanbur gibi çalgıları, tavla ve satranç gibi oyunları haram bilirler. Az ya da çok fark etmez şarabı ve diğer alkollü içecekleri haram kabul ederler. Kirli elbiselerle ve eti yenilmeyen hayvanların postları üzerinde namaz kılmazlar. Vücudun en şerefli bir parçası olan yüzü sol elle yıkamazlar. Resul bunun için buyurmuştur ki săg el yüz, sol el de taharet için. Sarhoş halde abdest almazlar. Mesh etmek yerine ayaklarını yıkamazlar. Namaz esnasında Yahudi'nin ve fâsık kimselerin arkasında namaz kılmazlar. Şeyhlere secde etmezler. Her cahil riyakarın müridi olmazlar. Sihir ve büyüyle aldatılmazlar. Bütün bunlara rağmen sizin fâsık, fâcir, şarapçı, uyuşturucu ot bağımlısı, itibarsız, taharet bilmez, namaz bilmez, dinsiz, haram yiyen, münafik ve mülhit müftüleriniz bu Taife-i Nâcîye-i Kızılbaş'ın ve İran memleketi sakinlerinin kanını ve malını helal kılmıştır. Frenk memleketlerinden gelen ordunuzun ekserisi İslam ve Müslümanlık adına sadece lailaheillallah demiş ancak bunu tasdik etmemişlerdir. Ehl-i İslamın şiarını bilmiyorlar. Onlar bir kez daha küfür ve sapkınlık çöllerine atılmış oldu. Allah kafirleri hidayete erdirmez. ${ }^{90}$

89 Kur'an: 2/159.

90 Kur'an: 5/67. 
Bilinmiş ola ki biz sizin ulemanızı birkaç açıdan kafir, âsık, bedbaht, karayüzlü biliyoruz. Onların durumunu tafsilatla değil özetle verme gereği duyduk. Onların çoğu Ehl-i Beyt düşmanıdır. Bütün ibadetleri terk edenlerden, bütün haramlara el uzatanlardandırlar; onlardan her biri Lut kavminin en kötüsüdür. Frenk, Yahudi, Hıristiyan ve Zenâdıka'dan mürekkep bütün küffar ile muaşeret halinde olmalarına rağmen kendilerini pak olarak telakki ederler. Çekinmedikleri köpek ve domuzu mubah bilirler; onlara temiz derler. Düzgün itikat, takva, taharet, movled ve makatın temizliği sizde bulunmayan şeylerdir. Sizin ulemanızın fazilet ve kemâlâtını çok iyi biliyoruz. En fazıl ve en alim olarak gördüklerinize, inadı bir kenara bırakarak fırsat verin de Acem diyarının cevvalleri ilmi bahislerde onlara nasıl üstün geldiklerini göstersinler. Allah'a hamdolsun ki kutlu devletimiz zamanında alim ve fakihlerimizin sayısı gökteki yıldızlar kadardır. Onlar kat i ve açık delillerle münazara meydanında ve sohbet meclislerinde dünyanın diğer alimlerini geride bırakırlar. Derin meselelere itirazda, hikmeti kavramada, müşkülatın inceliklerini keşfetmede, manaları derk etmede, kelimeleri anlamada, ahkama nüfuz etmede, mantıklı gerekçeleri yaymada, mantık, maâni, beyan, kelam, tefsir, fikıh, hadis, tarih ve ahbârın meselelerini çözmede öyle ustadırlar ki melekler bile onlara göklerden aferin yağdırır. İnsafa gelip ve basiret gözünüzü açarak onların müşkülatını halletseniz gözünüz mü kör olur veyahut bu manaları idrak etmekle ölür müsünüz? Şeytan, sapkınlık kilidini, sizin kalplerinize öyle sağlam vurmuş ki onlar hala Kur'an’ düşünmezler mi ?’1 manasından gafil bir halde hak, İslam, şeriat, ehl-i yakîn ve Ehl-i Beyt-i tayyibîn-i tahirîn yolundan sapmısssınız. Allah kime hidayet ederse kimse onu sapturamaz. ${ }^{92}$

Ey kâfir! Eğer kurtuluş arıyorsan

Siyahtan ve beyazdan gec

Ali'nin evladın imamın olarak bil

Günahkârlı̆̆ını çok düs̈̈nme

Ĕger Ali'ye candan kul olursan

Her iki cihanda da padişah sensin

Cümle zerreler ondan bir zerredir

Gökteki kuşlar, karınca ve balık

Münker ve nekir bana sorduklarında

Mezhebime şahadet edeyim

91 Kur'an: 4/82.

92 Kur'an: 39/37. 


\section{Zülfikar'in şahinin kuluyum}

Hâricîlerden neden korkayım ki

Ey Haydar'in hanedanına düsman olanlar

Kaçmayın sizinle işimiz vardır

Mezhebinizin ve Osmanlı kanunlarının rezaletine rağmen Mervan'ın yolunun reisleri, Şia taifesini Rafızî addetmiş ve onlar için Şia-yı şenîa yazmışsınız. Bilmiyorsunuz ki Hazret-i Kâinât'ın bereketli zamanlarında bu isim ve lakapların hiçbiri bilinmiyordu. Oysa Şia’nın mübarek ismi Hazret-i Seyyid-i Enbiyâ zamanında sahabe ve diğerlerinin arasında biliniyordu. Selman-1 Farisî, Ebuzer Gıfârî, 'Ammâr-1 Yâsir, Ebu Eyyüb-i Ensârî, Ebi Ke’b, Mikdâd-1 Esved, Mâlik-i Eşter, Abdullah-1 Abbas ve diğerleri gibi sahabeden birkaçı -ki Resul menkıbelerde onları övmüştür- hem muvafık hem de muhalif kitaplarda zikredildiği gibi savaş ve normal zamanlarda sürekli Emîrü'l-Müminîn, İmamü'l-muttakîn, Yảsubü'ddin, Esedullahü'l-Gâlib Ali b. Ebi Tâlib’in hizmet ve mülâzemetinde idiler. Allahü Teâlâ Ali'nin fazileti ve sahip olduğu yüce mertebe konusunda İbrahim Halil'e bilgi verdi. O da şöyle dua etti: Allahỉn beni Ali'nin şíasından eyle. Allahü Teâlâ onun duasını kabul etti ve dedi ki seni onun şi'asından eyledim. Bu hikâyeyi Kur'an'da tekrar dile getirdi ki şüphesiz ki İbrahim de onun taraftarlarındandr. ${ }^{93}$ Günümüze Ali'nin Şi'ası lakabı kalmışıı ve baki kalacaktır da. Dünyanın bütün âlimleri de çok iyi bilir ki Sünni adı İmamü’l-muttakîn Ali b. Ebi Tâlib ile sapkın Muaviye arasında yaşanan savaşlar zamanında ortaya çıkmıştır. Emîrül-Müminîn' in ordusu Ali Şi'ası, Muaviye'nin ordusu ise Sünni olarak şöhret bulmuştu. O iki kişinin askerleri karşı karşıya geldiklerinde birbirlerine "sen Şii misin yoksa Sünni misin? şeklinde soruyorlardı. O da ben Sünni'yim diyordu. Burada Sünni, Muaviye'nin geleneğini devam ettirerek Emîrü'l-Müminîn Ali b. Ebi Tâlib’e küfreden anlamına geliyordu. Sünni adının alınmasından maksat peygamberin sünnetini sürdürmek ise o zaman neden Şia taifesi Sünni olmasın? Zira Şia nezdinde peygamberin sünnetine uygun ibadetler haddinden fazladır. Gece gündüz birçok rekât, mübarek Ramazan ayında bin rekât onlar nezdinde kabul görmüştür. Onlara düşman olanlar nezdinde ise bu çok az kabul edilir. Teravih dedikleri Ömer b. Hattâb'in lanet onun üzerine olsun sünnetidir, Allah'ın elçisinin sünneti değil. Yoksa bu taife Resûl'un yüce sünnetlerinin hepsine uyup onunla $\mathrm{m}$ amel ediyorlar? Öyleyse Sünni olarak adlandırılmasından maksadın Ehl-i Beyt'e ve onun tabilerine, Şia muhiplerine düşmanlık etmek olduğu anlaşıldı. Bizim için bizi zemmedecek bir

93 Kur'an: 37/83. 
isim bulmuşsunuz ama bilin ki o isim bizim için övünç kaynağıdır. Bize Rafızî diyorsunuz. Biz de sizi Nasibî, Haricî, Yezidî, Nasrânî, Kadarî, Mervânî, münafik, Âl-i Muhammed'e zulmeden ve Ehl-i Beyt'e düşman olarak biliyoruz. Vesselam.

"Mezhebinizi terk edin, sahabeye küfretmeye tövbe edin, nedamet getirin ki sizinle sulh yapabilelim” şeklindeki boş sözlerinize cevap vermek gerekirse; bilmiyor musunuz ki

\section{Haşr gününde mezardan başımızı kaldıracak \\ Osman' , Ebabekir ve Ömer’i lanetleyecĕgiz}

Âl-i Muhammed'in şiilerinden birinin mezheplerini değiştirdiklerini, Âl-i Muhammed'in yoluna muhalefet ettiklerini hiç kimse hiçbir diyarda hiçbir zaman ne görmüş ne de duymuştur. Ama bir ay ve bir sene geçmiyor ki kötü itikatlı imansız Sünnilerden bin kişi mezheplerini değiştirmesin ve Ehl-i Beyt'in doğru yolunu seçmesin. Âl-i Muhammed'in mevâlî ve şiileri günden güne artıyorlar. Öyle ki Rum mülkünde, Mâverâünnehr ve Hindistan'da kaç yıl önce 500 kişiden fazla Şii yoktu. İçinde bulunduğumuz 961/1554 yılında her diyarda beş yüzden fazladırlar. Günden güne de artmaktadırlar. İnşallah çok yakın zamanda dünyanın bütün insanları bu parlak mezhebi tercih edecekler, bu mübarek cemaate düşmanlık olmayacak. Zira uğursuzluktur. Emîrü’l-Müminîn Ali b. Ebi Tâlib şöyle buyuruyor: Ancak yok olmayı göze alan bir hanedan biz Abdülmüttaliboğullarina düşmanlık eder. Ancak uyuz hastalı̆̆ına yakalanmıs olan bir köpek bize havlar. Buna inanmayanlar, denesinler. Eğer bu sözlerle ilgili bir şüpheniz varsa ibret gözüyle bakın ve görün ki Âl-i Süfyân, Âl-i Mervân, Âl-i Berâmike ve Âl-i Abbas her tarafta yetmiş bin altın beşiğe sahipti ve onlardan her biri Ehl-i Beyt'ten ve onların dostlarından binlerce seyyid katletmişti. Mansur Halife Bağdad'ın dışında bir bina yapmış, Benî Haşim seyyidlerini taş ve kerpiç yerine duvarlara koyuyordu ki Seyyidü'l-Mürselîn'in soyu inkıtaya uğrasın. Her yerde Haydar-1 Kerrâr'ın binlerce şii/taraftarını öyle katlettiler ki bu mezhep ve taifeden neredeyse hiç iz kalmadı. Bu batıl çabalarına rağmen, bu saydığım taifeden ne iz, ne mezar, ne mürit, ne nesil ne de zürriyet kaldı; hepsi kökünden söküldü. Soyları kurudu. Cihangir padişahların elinde onların her biri bir bela ve mihnete müptela olarak cehenneme kavuştular. Helak olmaları ve köklerinden sökülmelerinden sonra seyyidlerin üzerindeki bu zahmet ve eziyet ortadan kalktı. Bugün doğuda, batıda, kuzeyde ve güneyde yüce mertebeli seyyidler yıldızlardan da fazladırlar. Hepsi de makam, mevki, kudret ve zenginlik anlamında gayet refah içindedirler. Önceden hayır sahiplerinin ve ensarın sayıca az olması, düşmanların çok olması dolayısıyla takiyye vacipti. Şimdiyse 
avan ve ensarın sayıca çok olmasından dolayı takiyye artık mekruh belki de haram kılındı. Hindistan, Arab ve Acem belki güneşin doğduğu yerden battığı yere kadar Ehl-i Beyt ve seyyidlerin muhabbet sancağını dalgalandırıyorlar. Bundan önce bizimle çekişme ve düşmanlık halinde olan Maveraünnehr sultanları şimdilerde bizim kutlu emir ve yasaklarımıza tabi oldular; itaat makamındadırlar. Ülkeler alan sahib-kıran padişah, yüce hüsrev, ülkelerinin çokluğu ve azametiyle senden ve cihanın bütün sultanlarından daha seçkin olan Hindistan padişahı Hümâyûn, reayasına ve düşkünlere karşı merhametli ve adaletli birisiydi. Ordusunun arz gününde defterlerde kayıtlı beş yüz bin süvarisi ve on iki bin savaşçı fili olduğu bilinir. Bütün Hind sultanlarının hazineleri ona gelir. Ancak iş öyle bir mertebeye vardı ki melun şeytan fesat dolu hayallerle onun beynini yıkadı. Onun kibir ve zorbalığı öyle bir hal aldı ki saltanat ve ihtişam zirvesinden azamet ve büyüklük doruklarına uçtu. İnsanlar uzun bir müddetin ardından gördüklerinde ona cilve-i kuddûs adını vermişlerdi. Kendisine bağlı bütün memleket ve ordularda şeriat eski hükmünü yitirdi; ibadet ve taat yıkıldı. İlhad öyle bir dereceye ulaştı ki Rumiye-i şomiyede (uğursuz Rum ülkesi) olduğu şekilde fisk u fücur aleni bir şekilde gerçekleşiyordu. Bu arada memleket ayanı ve devlet erkânının toplandığı bir mecliste kâhin ve müneccimlerini çağırarak onlara dedi ki "Rüyamda ay ve güneş yanında bazı yıldızlar tahtımın ayağına indirler; benim hizmetime durdular. Bu rüyayı bana yorumlayın." Kâhinler ve müneccimler dediler ki "Göklerin hareketi ve gök cisimlerinden öyle anlaşılıyor ki Rum sultanı, İran padişahı, Turan hakanları, dünyanın diğer sultanları sana itaat edecekler; senin kutlu meclisinde yer alıp mülâzemet ve hizmetinde bulunacaklar. Bu olay çok yakında gerçekleşecek. Onların saltanat temelleri senin elinde harap olacak, o hanedanların hilafet ve azamet temelleri yok olacak.” Çağatay asilerinin önderi olan ümeradan birisi ayağa kalkarak şöyle dedi: "Âlemin padişahı, memleketlerin fethi ve alemin bütün sultanlarının ele geçirilmesinden sonra onlardan her biri için cennet meclislerinde bir oturma yeri ve düzeni tayin etmeyi buyursunlar.” Hümâyûn padişah da şöyle buyurdu: "Mâverâünnehr hanları filan yerde, İran padişahları filan yerde otursunlar. Rum ve Frenk sultanı ise filan yere yakın otursunlar." Bunun gibi fesat dolu hayaller, şeytani vesveselerle onun dünyasını değiştirmişti. Hazinesi ve ordusunun çokluğu onu kibirlendirmişti. Ancak ansızın kaza ve kader öncüleri tek seferde onun devlet ve azamet elbiselerini çıkarıp atıp, azl ve zıllet palasını ona giydirdi. Bütün azametine, kudretine cilve-yi kuddûsî yakıştırmalarına, fillerine, sayısız askerlerine ve hesapsız hazinesine rağmen kendi tabilerinden biri olan Şîr Han-1 Afgânî tarafından büyük bir yenilgiye uğratıldı. Bütün saltanatı ilahi kahr ve gazap denizine gark oldu. Onun tüm memâlik-i mahrûsası elden çıktı. İş öyle bir dereceye vardı ki 
hiçbir memlekette kalamaz hale geldi. Kandahar'a kadar geldi. Orada da hanedan düşmanlarından birisi, sürekli ağabeyi ile düşmanlık içinde olan kardeşi Kâmrân askerlerini toplayarak onun önünü kesti. Ona karşı savaştı. Oradan kendi yakınlarından az sayıdaki adamıyla kaçmayı başararak canını Horasan sınırına attı. Bizim devlet evliyamıza sığınarak kurtuldu. Göksel haberciler onun kulağına şu haberi ulaştırmışlardı: "Savaş esnasında kibir ve zorbalık ilahi dergâhın beğeneceği bir davranış değildir. Asılsız sözler ve gerçekten uzak hikâyelerle savaş ateşi yakılmaz. Kibirli asileri, zorba mağrurları kısa sürede tedip sillesiyle mahvederler." Hümâyûn Padişah'ın içindeki şeytan, şimdi senin içine de girmiş, kibir ve zorbalık sende yer tutmuştur. Saltanatının ebediliği derdine düşmüşsün. Dünyaya ve bütün insanlığa fısk u fücur atarak, isyan ve korkusuzluğunla inat ve büyüklenme yolunu takip etmişsin. İlahi kahırdan, gerçek padişahın gazabından korkmuyor musun? Hümâyûn Padişah azamet, büyüklük, ordu ve hazine bakımından senin on, belki yüz katın eder. Ama gel gör ki o bile ilahi lütfun bereketiyle bu hanedana itaat etti. Başını eşiğimize koyarak itaat kemerini can beline bağlayıp kurtuldu.

\section{Devletimiz bu cihanda günden güne artmakta \\ Yardim ve iyilik istiyorsan feleklere bak \\ Hümâyûn Hind'den belip bana gulam oldu \\ Şu kutlu talihe, Hümâyûn'un bahtına bak}

Cihanın şahlarına, zamanın sultan ve hakanlarına layık olan şeyi yerine getirerek ona şefkat gösterdim. Bütün hazinem ve insan kaynaklarımla onun ordusunu teçhiz ettim. Bin tam teçhizatlı at ve ordumdan yirmi bin süvari ile onun ordusunu donattım. Büyük bir ihtişamla ordusuna nizam verdikten sonra onu Gazneyn ve Hindistan mülküne gönderdim. Muzaffer gazilerin talihiyle uğursuz kardeşi Kâmrân'ı mağlup etti. Onu ele geçirerek gözlerine mil çekti. Bütün Kandahar, Gazne, Kabil, Multân ve Afgan memleketlerini kılıç gücüyle alarak Hindistan memleketine yöneldi. Eğer şöhret bulmuş hakanlar, yüce sultanlardan birinin himaye ve riayet makamında iseler böyle olurlar. Senin yaptığın gibi değil. Üç yüz bin kişiyi toplayıp top arabaları, tüfek ve dört yıl yetecek savaş teçhizatıyla Elkas' ın himayesinde İran memleketine vardın. Bu diyarın etrafına vardıktan sonra bir gün bile kalamadın. En sonunda o biçareyi yüz belaya müptela edip mahvederek geri döndün. Bir Şii’nin dediği gibi:

Rumî Tebriz kapısına geldi ve kendisine s* çarak gitti

Tebriz kapısından s $^{*}$ a s ${ }^{*}$ ça dönüp gitti 
Bil ki bağışs sahibi Allah, güzel siretlerinin, nübüvvet ve velayet hanedanına olan saf itikatlarının, masum sıfatlarının, seyyidler, âlimler, salihler ve takva sahiplerini himaye etmelerinin bereketiyle bizim devlet sancağımızı dünyanın her yanına çekti ve çekecek; heybet ve ihtişamımız yeryüzünü kapladı ve kaplayacak; din düşmanları ise gam kuyularına atıldı ve atılacak da... Kafir, Müslüman, Frenk ve Hint bir yaşından yetmiş yaşına kadar alemin bütün sultanları bizim yüce dergahımız padişahlara layık hediyeler gönderiyorlar ve itaat, ittifak ve taraftarlıklarını ortaya koyuyorlar. Çok yakın zamanda bütün dünya Ehl-i Beyt'in doğru yoluna girecek, bizim kutlu devletimizle Kâbe-i Mu'azzamầnın kubbesinde Resul'ün hanedanının düşmanlarına ve Ehl-i Beyt'e inatçılık gösterenlere karşı teberrâlar yükselecek.

"Üç yıllık askeri teçhizatla ve büyük bir orduyla İran üzerine dört taraftan yürüyecek, Horasan memleketine kadar hiçbir yerde durmayacağız. Sizin kuvvet ve kudretinizi yok edecek, İran toprağını yokluk rüzgârına vereceğiz" şeklindeki sözlerinize verilecek cevaba gelince: Kudret, Allah'ın olmasına rağmen Fakat bütün işler Allab’a aittir ${ }^{94}$, Resul-i Kureyşîn nin feri ve azametine rağmen onun vasiler seyyidi her daim dua zamanında acz ve yenilgi makamında demişlerdir ki Allahım! Fakirliğimi, çaresizliğimi, acziyetimi ve muhtaçlı̆̆ımı bă̆ışla! Sen kalede oturan cüretkâr yaşlı keşişin bu büyüklenmesi dildedir sadece.

Bu Allah'ın sözüdür, eşek beyni yemiş vakarsız herhangi birisinin değil. Bu memleketleri yakıp yıkmak maksadıyla beş defa üç bin kişiden oluşan ordunla geldin. Seninle daha savaşmadan bile kendi kendine yenilgiye uğradın. Aciz ve perişan köpekler gibi bin bir güçlükle geri döndün. Her gelişinde senin uğursuz ordundan yüz bin kişi cehennemi boyladı. Binlerce at, deve, hazineler, top ve tüfeği Yezid ve Muaviye yolunda feda ederek kaçtın. Beş gün bile bir yerde kalacak, memleketlerimizden bir köy bile alacak takatin kalmadı. Van Kalesi hariç. Zira o kaleyi nankörler sana teslim etmişlerdi. Eğer Van topraklarına gitmek ve orayı almak isteseydik tıpkı defalarca kış mevsiminde karın üstünde top ve tüfeklerimizle kalelerini alıp ve yerle bir ettiğimiz gibi her bir kalede senin itimat ettiğin askerlerinden birçoğunun boynunu vurarak cehenneme gönderdiğimiz gibi birkaç gün içerisinde orayı alır, yerle bir ederdik. Bilmiş olasın ki bundan sonra toplar ve mancınıklar işe yaramayacak. Buralara geldiğin birkaç seferinde herkes de çok iyi bilir ki orduma seninle savaşmaları için emir vermedim. Buna rağmen her taraftan kan içen savaşçılar, yüce gaziler ve aslan tabiatlı savaş̧̧ı kurçiler kutlu ordumuzdan kaçarak senin orduna kadar gelmiş, bir defasında iki üç bin adamını

94 Kur'an: 13/31. 
öldürmüşlerdi. Bir dahaki sefere ordumuz seninle savaşmak için bizden emir bile beklemeyecekler. Askerinin kökünü kazıyıp Fırat Nehri kenarına kadar ardından saldıracak ve ordundan geriye eser bırakmayacaktır.

Allah'a andolsun ki eğer Allah'tan korkmaz, peygamberin şeriatına uymaz, hak mezhep olan Ehl-i Beyt yolunu dikkate almazsanız, acizlere ve çaresizlere karşı merhametli olmazsanız kırk gün içinde Van serhadinden darüll-küfr İstanbul'a kadar öyle bir yaparız ki mamur hiçbir yer geride kalmaz. Bu zaten çok yakında yaşanacak bir şeydir. Ekinleri tahrip edip nesilleri bozmak için çalışı ${ }^{95}$ ayeti, mezhep ve itikatta seninle uyumlu olan dinsiz Ermeni sıfatlılar içindir. Onları yok etsinler, o taifeden bir kişi bile kalmasın. Bu batıl davaların, kibir ve zorbalığın en sonunda senin ve uğursuz Rumîlerinin başına dert açacak. Zira böyle arzulara sahip kimselerin fitrat ve mizacı fesat, zulüm ve kötülükle yoğrulmuştur. Şeytan senin kötü mizacının verimsiz topraklarına, tayyibîn-i tahirîn hanedanına ve onların takipçilerine olan düşmanlık fidanını ekmiş. Onun meyveleri bu dünyada çok yakında senin uğursuz zatına geri dönecektir. Senin Frenk mizaçlı dinsiz batınında zulme uğrayan her iki tarafın da reayasına merhamet yer almaz. Gör bak zalimlerin akıbeti ne oldu akıbetini de mi düşünmüyorsunuz?

\section{Ey zalim! Ettiğin cevr ü cefanın sonundan kork Ey Hâricî! Dert sahiplerinin feryatlarından kork Ey Nasibî! Kimsesizlerin dertlerinden kork Insandan korkmuyorsan bari Allabin kahrindan kork}

"Bu sefer Irak, Azerbaycan, Fars, Kirman ve Horasan memleketlerini yerle bir ettikten sonra geri döneceğiz” şeklinde öne sürdüğün batıl davaların ve alakasız bir şekilde yazdığın boş sözlere karşı diyebilirim ki bu ibarelerin içinde su olmayan kuyuya, yağı olmayan kandile, anlamı olmayan sözlere, can olmayan kuru tene ne de çok benzemektedir. Bu lafların Azerbaycan halkının kulağına gidecek olsa senin sakalına gülerlerdi. Zira Elkas'ın rehberliğinde dört yüz bin kişiyle Azerbaycan'a yönelip Tebriz’e konmuştun. Tebriz halkı birlik ve bu yüce hanedana olan bağl1lık sancağını yükselterek Osmanlı ordusunun, o Mervan taifesinin çokluğundan zerre kadar korkmadan dört taraftan senin üzerinden suyu kestiler. Pazarda sana bir manlık eşya bile satmadılar. Öyle ki ordugâhında bir testi su bile bir eşrefîye çıkmıştı. [Şehrin] kapılarını ve sokaklardaki mevzileri muhkem hale getirerek seninle savaştılar. Sırf bu olaydan dolayı intikam almak, onları yağmalamak ve

95 Kur'an: 2/205. 
karşı koymak aklına gelmişti. En sonunda Elkas, senin kokuşmuş beynindeki kibir rüzgârını söküp atmış, çıkarmış ve demişti ki "eğer senin bütün askerin bu şehre girecek olursa hiç kimse canlı olarak dışarı çıkamaz. Her birini bir köşede yakalayıp cehenneme gönderirler. Azerbaycan'ın süvari ve piyadelerinin kılıç ve ok darbeleriyle ordun yok olur." Sen pişman olmaya başlayınca gece yarısı Tebriz havalisinden kaçtın, köpekler gibi iki menzili bir menzil ederek canını Van'a zor attın. Senin uğursuz askerlerinden her biri bir tarafa kaçıyorlardı. Biz de yüz bin deri yüzen, savaşçı, kaplan tabiatlı, yardım bulmuş Kızılbaş ordusuyla beraberdik. $\mathrm{O}$ askerlerden her biri tepeden tırnağa zırha bürünmüştü ve aslanlar gibi kükrüyorlardı. Suya dalan balıklar gibi, düşmanın can cevherini kalp sedefinin içinden çıkarıyorlardı. Su kenarında savaşan timsahlar gibiydiler. Bir hamleyle savaşçı aslanların kalbini çıkarabilirlerdi.

\section{Aslanı yenen savaş̧̧ gençler \\ Hepsi de aslan gibi savaşa alışık}

Bütün ordumla senin arkandan hareket ettiğimizde bir karar alarak ordunu Bağdad tarafına gönderdin, sen ise din ashabı gibi olan muzaffer Kızılbaş gazilerinin kılıçlarının korkusundan İslambol tarafına kaçtın. "Elkas topladığı orduyla Kürdistan yolundan Acem'e yöneldi” şeklinde halk arasında bir söylenti yaydın. Gazilerimiz olur da çadırlara ve bazı hazinelere ulaşır ve tecavüzatta bulunur diye ondan endişe etmişlerdi. Büyük emirler, ricalarda bulunarak beni bu işten geri çevirdiler. Nam sahibi kardeşim Ebu’n-nasr Behram Mirza'yı bazı askerlerle birlikte o tarafa gönderdik. On gün içinde cahil Elkas'ı Bağdad'a kadar kovaladılar. Ordusunun büyük kısmını kılıçlarına lokma yaparak geri döndüler. Yoksa seni insan avcısı gazilerimin kılıçlarına lokma etmeden dönmem imkânsızdı. İstanbul'a kadar peşinden gelerek hiçbir menzilde konmanıza izin vermezdik. Aramızda geçen bütün bu olayları dünyadaki bütün insanlar biliyorlar. Böyle boş sözler yazarak, kibir ve zorbalık taslayarak "şöyle böyle yapacağım" diye kendini bize göstermek istiyorsun.

Çok iyi biliyorsun ki insanların gözünde hakir, itibarsız ve zelil duruma düşmüşsün. Sizdeki zulüm, fısk, küfür ve bedbahtlık bütün insanlığın bildiği şeydir. Yıllarca sizin yolunuzu gözleyenler ve mezhep ve itikat konusunda sizinle uyumlu olanlar bu esnada bu durumdan haberdar oldular ve sizden ümidi kestiler; sizi yermek ve lanetlemekle meşguller.

\section{Sana adil diyen bir cehennem köpeğidir}

Sana itibar edene lanet olsun 
Gayb habercisi akıl kulağına şunları ulaştırıyor: Yakın zamanda o hilekar, Seyyid-i Muhtar'ın hanedanına olan düşmanlık ve zulmünden aldanarak saltanat ve hüsrevliğin emanet elbiselerini çkaracak ve nasıl ki İldırım Bayezid alemi fetheden sahib-kıran Emir Timur Gurgânînnin Allah onun delilini nurlandırsın elinde tutsak olduysa sen de bin zillet ve perişanlıkla gazilerin elinde esir olacaksın. Yaratıcının dergahından kovulmuş, insanlara rüsva olmuş bir şekilde teberrâ̂ler senin başını gürz ve baltalarıyla parçalayarak yerle bir edecekler. Bir de onlar için demir kamçılar vardır!96 tam da bunu anlatır. Benî Ümeyye ve Benî Mervan'ın libası olan siyah hilatların yerine neft fiçıları başına ve bedenine dökülecek ki Onlarn gömlekleri katrandandır. ${ }^{97}$ ayeti ondan bir kinayedir. Seni cehennemin mihnet dolu meydanında yakacaklar. Teberrâiler, gaziler, şiiler, mevaliler ve ittifak etmişler demir şişleriyle senin hizmetinde kuyruğa girecek, müeddebâne bir tarzda sana şöyle hitap edecekler: Ey Süleyman Han! Ey imansız Sünnilerin önderi! Ey Hâricîlerin reisi! Ey mülhitlerin serveri! Yerin mübarek olmasın. Azap melekleri âlemlerin Rabb'iyle görüştükten sonra seni cehennemin en dibindeki ateşten tahta gönderecekler. Duyulan saygıdan dolayı senin yerini cehennemin en dibi olarak tayin edecekler. Şüphe yok ki münafiklar cehennemin en alt katındadırlar ${ }^{98}$ ayeti ondan bir kinayedir. İşte o zaman cahil ümera, vüzera ve bilginler, İstanbul'un ahalisi, mevalisi, erbabı, dervişleri, şeytanın bulunduğu yerlerde inzivaya çekilenler küfrün yanıcı kuşaklarını ve kızgın kapları hediye olsun diye senin elinin üzerine saçacaklar. Cehennemin en dibinde seni tebrik etmeye gelecekler. Rabbim beni bereketli bir menzilde konaklat. Şüphe yok ki konuk ağırlayanların en hayırlısısın ${ }^{99}$ ayeti ondan bir kinayedir.

Beğenilmemiş mektubunun cevabını okuman, Allah'a kulluk için çalışman, cahillikten, batıl olandan ve düşmanlıktan uzak olman gerekir. Nebevî şeriata uymalı, Murtaza'nın yolunu kulluğa kabul edilme vasıtası yapmalısın. Kibir ve zorbalığı aklından çıkar at! İnsanların içinde fena işlere bulaşma! İslam yolunu seç ve taassuptan vazgeç! İnadını bir kenara bırak ki masum imamların şefaatinden nasibini alabilesin. Saadete erişesin. Kurtuluş, hidayete uyanlarındır. ${ }^{100}$

Safer 961/Ocak-Şubat 1554

96 Kur'an: 22/21.

97 Kur'an: 14/50.

98 Kur'an: 4/145.

99 Kur'an: 40/29.

100 Kur'an: 20/47. 